\title{
Divergent growth trends and climatic response of Picea obovata along elevational gradient in Western Sayan mountains, Siberia
}

\author{
Elena BABUSHKINA1* (iD http://orcid.org/oooo-0oo2-1355-4307; Ne-mail: babushkina70@mail.ru \\ Liliana BELOKOPYTOVA1 (iD http://orcid.org/oooo-ooo2-8475-7304; e-mail: white_lili@mail.ru \\ Dina ZHIRNOVA1 iD http://orcid.org/oooo-0oo2-5189-5700; e-mail: dina-zhirnova@mail.ru \\ Anna BARABANTSOVA² (iD http://orcid.org/oooo-0oo2-1002-989X; e-mail: anna-gav.103@mail.ru \\ Eugene VAGANOV3, 4 (iD http://orcid.org/oooo-ooo1-9168-1152; e-mail: eavaganov@hotmail.com \\ * Corresponding author \\ 1 Khakass Technical Institute, Siberian Federal University, Abakan, 655017, Russia \\ 2 National Park “Shushensky Bor”, Shushenskoe, 66271o, Russia \\ 3 Siberian Federal University, Krasnoyarsk, 660o41, Russia \\ 4 Sukachev Institute of Forest, Siberian Branch of Russian Academy of Sciences, Krasnoyarsk, 66oo36, Russia
}

Citation: Babushkina E, Belokopytova L, Zhirnova D, et al. (2018) Divergent growth trends and climatic response of Picea obovata along elevational gradient in Western Sayan mountains, Siberia. Journal of Mountain Science 15(10). https://doi.org/10.1007/s11629-018-4974-6

Received: 04 April 2018

Revised: 13 July 20182018

Accepted: 2018

\begin{abstract}
In mountain ecosystems, plants are sensitive to climate changes, and an entire range of species distribution can be observed in a small area. Therefore, mountains are of great interest for climate-growth relationship analysis. In this study, the Siberian spruce's (Picea obovata Ledeb.) radial growth and its climatic response were investigated in the Western Sayan Mountains, near the Sayano-Shushenskoe Reservoir. Sampling was performed at three sites along an elevational gradient: at the lower border of the species range, in the middle, and at the treeline. Divergence of growth trends between individual trees was observed at each site, with microsite landscape-soil conditions as the most probable driver of this phenomenon. Cluster analysis of individual treering width series based on inter-serial correlation was carried out, resulting in two sub-set chronologies being developed for each site. These chronologies appear to have substantial differences in their climatic responses, mainly during the cold season. This response was not constant due to regional climatic change and the local influence of the nearby Sayano-Shushenskoe Reservoir. The main response of spruce to growing season conditions has a typical elevational pattern expected in mountains: impact of temperature shifts with elevation from positive to negative, and impact of precipitation shifts in the opposite direction. Chronologies of trees, growing under more severe micro-conditions, are very sensitive to temperature during September-April and to precipitation during October-December, and they record both inter-annual and long-term climatic variation. Consequently, it would be interesting to test if they indicate the Siberian High anticyclone, which is the main driver of these climatic factors.
\end{abstract}

Keywords: Climate change; Tree-ring width; Growth trends; Climate-growth relationship; Picea obovata; Elevational gradient 


\section{Introduction}

Global warming has a significant impact on ecosystems of high latitudes and elevations. Mountain ecosystems are more vulnerable to climate change due to the limited area and steep gradients of external conditions; therefore, they can serve as indicators of its ecological consequences (Becker and Bugmann 2001; Anderson and Goulden 2011; Tognetti and Palombo 2013). On the other hand, a variety of climatic and landscape conditions provides a high diversity of vegetation in mountains, primarily along of elevational gradients (Körner 1995, 2003, 2007; Becker et al. 2007; Sang 2009; Xu et al. 2017; Fauquette et al. 2018). The distribution of mountain vegetation is closely connected with the heat and moisture supply, primarily depending on elevation (Hamann and Wang 2006; Li et al. 2014). At the local level, the climatic response of vegetation is regulated by both abiotic factors and biotic interactions (Case and Duncan 2014; Wieser et al. 2014; Müller et al. 2016). As a result, in mountains climate change is reflected in both the growth and development process of plants and their distribution ranges (Gottfried et al. 1999, 2012; Körner 2000, 2009; Gonzalez et al. 2010; Subedi et al. 2015; Rumpf et al. 2018). Inconsistent and sometimes contradictory responses to the warming (both positive and negative) observed in empirical studies can be explained by the complexity of interacting factors on local and individual scales (Wilmking et al. 2004, 2005; Lyu et al. 2016; Latreille et al. 2017; Wypych et al. 2018), but this question is far from being completely answered.

A detailed investigation of the relationships between trees and environment is necessary to better understand the pattern of mountain forest ecosystems' response to warming. Many works are focused on revealing the response of woody plants to a temperature increase at the upper limit of their growth, i.e. under the conditions of a clear limitation of growth by temperatures (Wang et al. 2005; Jiao et al. 2016; Jochner et al. 2018). The majority of researchers observed reliable tree growth response to the variation of spring-summer air temperature (Naurzbaev and Vaganov 2000; Briffa et al. 2004; Chen et al. 2015; Wang et al. 2015; Helama and Sutinen 2016; Zhang et al. 2016). However, some works have also revealed winter temperatures' effect on the growth of woody plants on both upper and northern tree-lines, e.g. in Scandinavia, Canada, and on the Tibetan Plateau (Jonsson 1969; Mäkinen et al. 2000; Miina 2000; Chhin et al. 2008; Lo et al. 2010; Helama and Sutinen 2016; Lyu et al. 2016). These results are important because the most pronounced trend of modern warming is observed during the cold season in the continental part of Asia including Siberia (Chapman and Walsh 1993; Rogers and Mosely-Thompson 1995; Savelieva et al. 2000; Kattsov and Semenov 2014; Kug et al. 2015).

The features of the mountains include a significant elevational spread not only of forest ecosystems, but also of individual species of woody plants (Vitasse et al. 2009). Examining the growth of one species at different elevations makes it possible to consider the variability patterns of the climatic response from two sides: 1) due to spatial (mostly elevational) temperature gradient with average lapse rate of $0.65^{\circ} \mathrm{C}$ per $100 \mathrm{~m}$ of elevation (Maurer et al. 2002; Hamlet and Lettenmaier 2005; Chae et al. 2012; Wypych et al. 2018 ); 2) due to the temperature temporal variation at a fixed elevation (Wilmking et al. 2004, 2005; Driscoll et al. 2005; Lei et al. 2016). However, we hypothesize that due to highly mosaic landscape, in mountains integrity of the observed climate-growth relationships can be achieved only if small-scale (local and individual) factors influencing tree growth are also taken into account.

In the conditions of the Western Sayan mountains, the Siberian spruce (Picea obovata Ledeb.) is a species spread practically from the foothills to the upper treeline. This region is convenient to perform research in moderate latitudes of continental Asia, because it is a part of its vast mountain system (including Sothern Siberia, Mongolia, Northern China, Tibet etc.), but is not well-studied from a dendroecological point of view. To close this gap, in the present work we pursued several objectives: 1) to analyze climatic dynamics in the Western Sayan mountains; 2) to perform dendroclimatic analysis of Siberian spruce along the elevational gradient across all its range; 3) to examine if small-scale factors significantly impact patterns of spruce growth or climate-growth relationships in the study area. 


\subsection{Study area}

The study was conducted on the Borus Ridge, which is located on the northern macroslope of the Western Sayan Mountains (Figure 1). The foothills begin at 300-400 m asl, and the maximum elevation of the ridge is $2318 \mathrm{~m}$ asl. This variety of elevations yields vegetation cover diversity, but most of the area is occupied by taiga forests. Conifer trees in the study area are represented by several species: Scots pine (Pinus sylvestris L.) and Siberian larch (Larix sibirica Ledeb.) grow from foothills up to $\sim 1000 \mathrm{~m}$ asl with occasional trees at higher elevations. Siberian fir (Abies sibirica Ledeb.) can be found throughout the forest belt. The range of Siberian spruce (Picea obovata Ledeb.) and Siberian pine (Pinus sibirica Du Tour) is $\sim 500-1400 \mathrm{~m}$ asl, but below $800 \mathrm{~m}$ asl Siberian pines are rare. In the foothills, forests border on the steppes of the Minusinsk depression, and in the highlands they are replaced by alpine meadows and barren rocks at an elevation of 1300-1500 m asl (depending on slope direction). Soils of the forest belt are loamy, shallow, and podzolic. Throughout all the elevations, there are numerous outcrops of solid rocks and stone taluses. The thickness of the fertile soil layer decreases on steeper slopes; conversely, the quantity of hard rock increases with slope steepness.

The climate of the study area is sharply continental, with cold winters and relatively hot summers. Mean annual temperatures are close to zero. In summer, the air temperature can rise episodically to $+40^{\circ} \mathrm{C}$; in winter it can drop to $-50^{\circ} \mathrm{C}$. Precipitation during the year is unevenly distributed, with the maximum in July and minimum in February-March. With increases in elevation, the temperature lapses and the amount of precipitation increases, especially snowfall. The annual amount of precipitation rises from $\sim 350 \mathrm{~mm}$ in the valley to more than $1200 \mathrm{~mm}$ at the treeline. The dynamic of the regional climate in recent decades has been greatly influenced by the creation of the large and deep Sayano-Shushenskoe Reservoir (surface area is $620 \mathrm{~km}^{2}$, the greatest depth is $220 \mathrm{~m}$ ) on the Yenisei River. The filling process of the reservoir started in 1978 and continued until 1990 (Popov and Shatravskii 1994).

\subsection{Sampling sites}

The samples were taken from Picea obovata trees in the National Park "Shushensky Bor" at three sites along the elevational gradient (Figure 1, Appendix 1): $\sim 520 \mathrm{~m}$ asl (LOW, $52.83^{\circ} \mathrm{N}, 91.45^{\circ} \mathrm{E}$ ), $\sim 960 \mathrm{~m}$ asl (MID, $52.80^{\circ} \mathrm{N}, 91.48^{\circ} \mathrm{E}$ ) and $\sim 1320 \mathrm{~m}$ asl ( $\mathrm{HIGH}, 52.81^{\circ} \mathrm{N} 91.51^{\circ} \mathrm{E}$ ). Site selection was determined by logistic accessibility requirements and the range of spruce in the study area, i.e. from the lower limit to the upper one. The territory status as a conservation area ensures the minimal human impact on these ecosystems. However, all sites are located within $10 \mathrm{~km}$ east of the dam of the Sayano-Shushenskoe Reservoir. The LOW site is covered by fir-birch forest with individual trees of Siberian and Scots pines (canopy closure $>80 \%$ ); spruce trees (average tree height $~ 30 \mathrm{~m}$, their diameter at breast height (DBH) 30$50 \mathrm{~cm}$ ) grow in the valley near the stream and on the adjacent slope of the northern orientation. The MID site is covered by Siberian pine forest mixed with Scots pine and spruce (100\% canopy closure, 10\% of spruce trees, tree height $\sim 20-25 \mathrm{~m}, \mathrm{DBH} 20-40 \mathrm{~cm}$ ), in the undergrowth young spruces are more abundant $(\sim 30 \%)$; the slopes are east- and west-oriented. The HIGH site is also covered with Siberian pine forest with some fir and spruce, but it is sparse ( $<50 \%$ canopy closure); most of the spruce trees (tree height $10-15 \mathrm{~m}$; DBH 15-30 cm) grow in the small north-oriented valley with a stream and on the east-oriented slope covered by stone runs. Highly heterogeneous terrain yields landscape and soil variety within each site up to the scale of individual trees.

\subsection{Dendrochronological data}

Sampling was performed by selecting 30-40 adult living trees from each site having a relatively small area (diameter $<200 \mathrm{~m}$ ), with the aim of minimizing effects of competition (closest neighbors at distance $>2$ $\mathrm{m}$ ), tree social status (only dominant and sub-dominant trees were selected), and disturbance events (excluded trees with signs of damage). Due to landscape unevenness, growth conditions were noted for each individual tree. The samples (cores) were taken with the incremental borer at breast height $(\sim 1.3 \mathrm{~m})$. The 
collection, transportation, and preparation for measurement of samples were carried out using standard dendrochronology techniques (Cook and Kairiukstis 1990). Tree-ring width (TRW) was measured with a semi-automatic system LINTAB 5 to the nearest $0.01 \mathrm{~mm}$ in the TSAP Win program (Rinntech 2011). Cross-dating of TRW series was carried out in the COFECHA program (Holmes 1983). In the raw series, long-term non-climatic trends associated with age, size and stand dynamics were fitted as individual exponential functions and then removed by dividing the measured TRW values by the trend function values. As a result, standard indexed individual series were obtained; then they were averaged with a bi-weighted mean into generalized chronologies. The standardization and generalization of chronologies were carried out using the ARSTAN program (Cook and Krusic 2005). The generalized age curves for each site were approximated by negative exponential functions fitted using the method of least squares.

\subsection{Climatic data}

For Siberia and especially its mountainous regions, a relatively low density of settlements and logistical issues are typical. As a consequence, weather stations in the region are located at large distances from each other, which severely limits their selection. In this study, the local weather station Cheryomushki was selected as the main source of climatic data - namely, monthly and daily series of mean temperature and amount of precipitation for 1951-2015. This station is located in the foothills of the Borus Ridge, within $4 \mathrm{~km}$ to the northeast from the dam of Sayano-Shushenskoe Reservoir and in 4-9 km from the sampling sites (Figure 1). On the base of monthly series, temperatures and precipitation were integrated (mean value and sum, respectively) during cold (November-March) and warm (April-October) seasons, defined by using a $\mathrm{O}^{\circ} \mathrm{C}$ temperature threshold in Cheryomushki. Additionally, corresponding monthly climatic series from two other weather stations were used to analyze regional climate trends and to estimate the elevational gradients of temperature and precipitation: Olenya Rechka (high mountains of the Western Sayan, $\sim 110 \mathrm{~km}$ to the east) and Minusinsk (Minusinsk depression, $\sim 100 \mathrm{~km}$ to the north). Coordinates and climatic characteristics of used weather stations are shown in Table 1.

To evaluate the timing of the vegetative season $\left(\mathrm{T}>+5^{\circ} \mathrm{C}\right)$ during certain years, average values of temperature were calculated for each month at Cheryomushki and Olenya Rechka stations. Then, average monthly temperatures were calculated for each site from the two stations' data with interpolation based on the elevations of sampling sites and stations (Figure 2).

To determine the timeframe of the climatic impact on TRW, the moving (21-day window and 1-day step) series of mean temperature and precipitation amount were calculated based on daily data from the Cheryomushki station. These series have the same length of 65 years (1951-2015) as the original daily data, which should ensure sufficient reliability of the revealed patterns in the climatic signal. A similar approach with windows of 10-25 days has already been used to analyze the climatic signal in chronologies not only of TRW, but also of other wood structure parameters (Helama and Sutinen 2016; Carrer et al., 2017; Castagneri et al., 2017; Belokopytova et al. 2018).

\subsection{Statistical analysis}

This study utilized the following statistical characteristics of TRW chronologies: arithmetic mean; standard deviation; mean inter-serial correlation coefficient (Pearson's paired correlation coefficient between every pair of individual series in the set in question, calculated with a 50-year window and 1-year step and then averaged); signal-to-noise ratio $(S N R=N \cdot r /(1-r)$, where $N$ is the sample size, $r$ is the average inter-serial correlation coefficient); mean coefficient of sensitivity (the ratio of the modulus of two successive values' difference to their arithmetic mean averaged over the entire length of the series); and, first-order autocorrelation coefficient (Cook 1985; Shiyatov 1986; Cook and Kairiukstis 1990). For climatic series, only the arithmetic mean and standard deviation were used. The classification of the total set of individual trees sampled at the site into sub-sets was carried out with hierarchical classification using the complete linkage method; inter-serial correlation coefficients were used as a measure of the closeness between individual TRW series.

Time trends were calculated as a simple linear regression function. Linear relationships between variables (climatic factors and / or TRW chronologies) were estimated by Pearson's correlation coefficients 
and also by linear regression. Significance in correlation analysis and significance of differences between sub-periods in climatic series were tested using Student's $t$-distribution.

Statistical analysis was performed using Microsoft Excel, all TRW statistical characteristics but SNR were calculated in ARSTAN.

\section{Results}

\subsection{Comparison of climatic series and their dynamics}

The climatic trends during the period of the instrumental observations are uneven, and it is helpful to compare two 30-year consecutive sub-periods (cf. so-called climatic normal in WMO 2007): 1951-1980 and 1981-2010. Trends in the amount of precipitation are insignificant for all considered periods. During 19511980 the significant cold season warming by $0.81-0.97^{\circ} \mathrm{C}$ per decade was observed at Minusinsk and Cheryomushki stations, and during 1981-2010 all three weather stations recorded significant increase in warm season temperatures by $0.28-0.46^{\circ} \mathrm{C}$ per decade (Figure 3). Over the entire period of the instrumental series (1951-2015), significant positive trends are observed for temperatures of both cold $\left(1.06^{\circ} \mathrm{C}\right.$ per decade at Cheryomushki and $0.30-0.58^{\circ} \mathrm{C}$ per decade at other stations) and warm seasons (0.16-0.23 ${ }^{\circ} \mathrm{C}$ per decade), as well as the average annual temperatures (0.24-0.5 $6^{\circ} \mathrm{C}$ per decade).

A comparison of average annual and seasonal values of temperatures and precipitation between 19511980 and 1981-2010 sub-periods (Table 1) show that there was no significant change of precipitation. At the same time, the temperatures of warm and especially cold seasons have significantly increased. Cheryomushki station is characterized by higher winter temperatures compared to the other stations, especially after the construction of the dam, which led to an increase in local winter temperatures by $4.1^{\circ} \mathrm{C}$ in $1981-2010$ compared to $1951-1980$, while at other weather stations the increase is only by $1.1-2.0^{\circ} \mathrm{C}$. The increase in average temperatures of the warm period for these sub-periods is only by $0.6-0.7^{\circ} \mathrm{C}$, according to all three stations (i.e. only a long-term regional trend was observed).

The weather station Olenya Rechka is situated at a high elevation, the local climate there is characterized by lower temperatures and more precipitation compared to the other stations throughout the year, but a temperature lapse is observed primarily in summer, and a greater amount of precipitation is more pronounced in winter. Comparison of the Cheryomushki station's seasonal climatic series with respective series from other stations is shown in Figure 4 (analysis of separate monthly series is shown in Appendix 2). The temperature dynamic correlates very highly between all stations within the region, both for individual months and for the entire seasons. For precipitation, correlations are lower, however all correlations are still significant at $\mathrm{p}<0.05$.

Estimation of the average intra-annual temperature dynamics at the sampling sites (Figure 2) allowed to evaluate the timing of vegetative season $\left(\mathrm{T}>+5^{\circ} \mathrm{C}\right)$ at each site for both sub-periods. Along the elevational gradient, in 1951-1980 the average duration of the vegetative season decreased from 159 days (Apr 27 - Oct 3) at the LOW site to 138 days (May 9 - Sep 24) and 118 days (May 20 - Sep 15) at MID and HIGH sites respectively (i.e. its lapse rate is $\sim 5.1$ days per $100 \mathrm{~m}$ ). Regional and local warming has led to an increase in its duration by $\sim 8$ days and an earlier season onset by $\sim 5$ days in 1981-2010, compared with the previous sub-period. The elevational lapse rate, however, stayed the same.

\subsection{Tree-ring chronologies}

Initially, standard TRW chronologies were developed from all the samples at each site. The statistical characteristics of these chronologies are shown in Table 2. The most pronounced difference between chronologies along the elevational gradient was observed in the growth rate and age composition of the stand. With an increase in elevation, the radial growth of trees sharply decreases and its age curve becomes less steep (Figure 5). The age of trees, on the contrary, increases: at the upper limit of the spruce distribution, trees are on average 2.5 times older than on the lower one.

The standard deviation and sensitivity of local chronologies are relatively low. They are maximal at the upper boundary and minimal in the center of the spruce distribution range (Table 2, Appendix 3). But their changes along the gradient are not large. Mean inter-serial correlation coefficients are significant but low 
(0.24-0.27), but the maximal correlations between individual series reach 0.87. This indicates that trees growing within the site can be divided into different groups with significant differences in the growth dynamics, while retaining a certain synchrony of reaction to external conditions. Therefore, for each site, clustering was carried out based on inter-serial correlation, to distinguish reliably two sub-sets of trees, for which mean inter-serial correlation increased to 0.29-0.43. The age characteristics and sensitivity of the chronologies for the selected sub-sets do not differ from those for the full local sets; the standard deviation is slightly higher for most sub-sets (0.17-0.25 for sub-sets and 0.17-0.20 for full sets). Size of sub-sets A and $\mathrm{B}$ is comparable (differs less than twice) at all three elevations. It should be noted that the signal-to-noise ratio of the sub-set chronologies is slightly less than for the full sets due to their smaller size, but it is still sufficient to reliably reveal the common signal in TRW.

Comparing micro-conditions for A and B sub-sets of trees, we discovered that at each site, sub-set A mainly consisted of trees growing on steeper and stonier slopes; trees growing in more favorable microconditions (depressions of landscape with a deeper and less stony fertile soil layer) were mainly included in sub-set B (Appendix 4). Dynamics of the sub-set standard TRW chronologies is shown in Figure 6. At all elevations, sub-set chronologies have synchronous with each other inter-annual fluctuations, but during some periods there is a divergence in the low-frequency components of growth, which is especially pronounced after 1980: trees from sub-sets A at all elevations have a steep increment of TRW during this period, while sub-sets B show significant negative trends. Periods of divergence on a decadal scale were also observed earlier, e.g. at HIGH and MID sites in 1920-1960 the faster growth was observed in sub-sets B.

Within each site, the full local chronologies are highly correlated with sub-set chronologies (0.49-0.94). The sub-set chronologies' correlations between each other are lesser, but they are significant too (0.22o.40), slightly increasing with elevation (Table 3). Between the different sites' chronologies, correlations of different signs are observed depending on the sub-set; the correlations are most negative between the chronologies of the lower and upper spruce range boundaries (from -0.38 to 0.15). Chronologies from the middle of the range have some similarities with both boundaries. It should also be noted that when comparing chronologies from different elevation, correlations between sub-sets A are always positive (0.150.47), reaching a maximum when comparing MID A and HIGH A. Correlation coefficients between sub-sets $\mathrm{B}$ and between different sub-set types have wider variety of values.

\subsection{Dendroclimatic analysis}

To analyze the effect of seasonal dynamics of temperature and precipitation on spruce growth, correlations between TRW chronologies and moving 21-day series of these climatic variables were calculated (Figure 7). At all three elevations, the climate response of the sub-sets differs significantly. The most drastic difference is observed for the cold season from September to April, when all sub-sets A react positively to the temperature, and the sub-sets B have neutral (LOW, MID) or negative (HIGH) temperature response. In addition, sub-sets A at all sites experienced a more pronounced positive effect of precipitation in the first half of winter (October-December) and in spring (April-May). The climatic influence during the current growth season depended more on the site elevation, but its intensity was also slightly higher for sub-sets A. With increasing elevation, the response to May-June temperatures changes from negative to positive, while the response to precipitation turns from positive to negative. In the center of the spruce range, the climate-growth relationship is closer to the one observed at the lower boundary. In general, the response to the climatic factors of the growing season shifts to later dates as the elevation increases.

The homogeneous climate response during several consequent months leads to the conclusion that the climatic series integrated from monthly data for such a season have higher correlations with spruce growth (Table 4). E.g., reactions to the cold season temperatures and precipitation reach 0.32-0.51 and 0.32-0.37, respectively, for positively sensitive sub-sets A.

Since temperatures changed significantly over the decades under consideration, especially during the cold season, it was productive to compare 1951-1980 and 1981-2010 sub-periods. In this analysis, it should be taken into account that the short length of the series (30 years) leads to a decrease in the statistic reliability of revealed regularities. Nevertheless, there is a tendency toward shifting the correlations of spruce TRW with temperatures in the negative direction without regard to the elevation. For example, the correlations of the LOW site chronologies with the cold season temperatures changed from positive (up to 
0.57) to insignificant negative values (down to -0.14). At the HIGH site, for sub-set A the positive correlation (0.14) with cold season temperature was replaced by a negative one (0.20), and for sub-set B, the negative correlation strengthened from -0.23 to -0.36. The decrease in correlations of TRW with temperatures was also observed in May-June, but it was less substantial. There were no significant patterns observed in the dynamic of growth reaction to precipitation.

Analysis of low-frequency components of time series variation showed that the smoothed chronologies of sub-sets HIGH A and MID A (by 11-year moving average) have very high correlations with the smoothed series of September-April temperature (0.90 and 0.85, respectively) and October-December precipitation (0.79 and 0.72, respectively) (Figure 8). These smoothed series of climatic parameters of the cold season strongly correlate with each other as well (o.68), despite insignificant correlations in their series per se (o.19).

\section{Discussion}

This study revealed discrepancy of the spruce radial growth, which is related to winter temperatures and most contrastingly manifested at the upper limit of spruce distribution. It shows that possible reasons of divergence in woody plants growth (see review by D'Arrigo et al. 2008) can be more diverse by nature. In the investigated regional conditions, divergence is probably the result of a complex interaction of climate, soil and landscape of micro-site, and characteristics of individual trees (genetic, adaptive) or their groups. Such small-scale discrepancy was detected previously by Wilmking et al. (2004, 2005), who proposed sorting trees into groups of positive and negative "responders" in regard to direction of their reaction to current temperature trends.

\subsection{Regional climate}

Similar to other regions of Central Asia, warming in Southern Siberia is expressed primarily during the cold season, while summer temperatures increase more slowly (Chapman and Walsh 1993; Rogers and Mosely-Thompson 1995; Savelieva et al. 2000; Kattsov and Semenov 2014; Kug et al. 2015). Taking into account that winter temperatures also have a larger amplitude of year-to-year fluctuations in comparison with summer ones, we can assume a more significant influence of winter temperatures on vegetation of the study area in comparison with other regions. In addition, the regional trend is exacerbated by local winter mitigation after completion of the Sayano-Shushenskoe Reservoir dam. For example, according to Kosmakov (2001), the ice cover freeze-up in the reservoir near the dam occurs only in January, which is 1.52 months later than before the dam's construction. All of this makes Borus Ridge a promising testing ground for analyzing the impact of changing winter temperatures on mountain ecosystems.

Despite the considerable temperature gradients in the mountain areas, the analysis showed a very high uniformity of the temperature field variation within the region, i.e. the interrelations between the temperatures of different locations are practically linear, regardless of elevation. Weaker relationships between precipitation series indicate their relatively high spatial heterogeneity, but it should also be taken into account that the distance from the Cheryomushki station to the sampling sites does not exceed $10 \mathrm{~km}$. This allows using of its climatic series to analyze the climatic response of trees at different elevations with a high degree of reliability.

Olenya Rechka station is located at the same latitude but above the upper boundary of the spruce distribution. Using its data allowed simulation of local temperatures and estimation of the approximate timing of the vegetative season at all three sites, based on the known linear temperature dependence on elevation (Hamlet and Lettenmaier 2005; Chae et al. 2012; Wypych et al. 2018) and the uniformity of the temperature field within the region.

\subsection{Growth patterns of spruce}

The elevational gradients of the decrease in the duration and temperatures of vegetative season seem to yield a significant decrease in the wood cell production with elevation, due to a shorter period of cambial activity, and due to the positive relationship between temperature and cell division rate in the cambial zone 
(Vaganov et al. 2006; Begum et al. 2013; Rossi et al. 2014; Jiang et al. 2015; Kraus et al. 2016; Ziaco and Biondi 2016). Accordingly, TRW decreases for trees of all ages (Figure 5). The converse of this pattern is an increase in tree life-span along the elevational gradient. As is shown in several studies, this pattern is due to the interaction of a complex of factors associated with both vegetative season temperature decrease (because slower metabolism leads to a decrease in oxidative stress and in telomere length reduction in cells), and with the growth rate (e.g. minimization of size-related limitations of physiological effectiveness and tree durability) (Di Filippo et al. 2012, 2015; Körner 2016).

The coefficients of sensitivity of spruce TRW chronologies are low compared to other conifer species of the region (cf. Babushkina et al. 2011) and do not seem to depend on growth conditions, indicating stable growth and relatively low influence of year-to-year external conditions' fluctuations. Besides that, its values are comparable with the observations of other researchers for various spruces (Mäkinen et al. 2002; Savva et al. 2006; Sidor et al. 2015; Jiao et al. 2016; Lei et al. 2016), i.e. low mean coefficient of sensitivity is typical for spruce genera. Despite this, TRW of spruce can contain a significant climatic signal, which is confirmed by the findings of this study.

Low inter-serial correlation coefficients indicate that, apart from the general climatic influence, there are other factors within the site which make a significant contribution to the variability of growth on the scale of individual trees. Other observation of individual-scale factors' input in spruce growth patterns was made in Canada (Montoro Girona et al.2016, 2017) It is logical to assume that at the study area this role is played by micro-conditions (Barber et al. 2000; Kulagin et al. 2006; Monnier et al. 2012; Lange et al. 2016), which are characterized by high diversity and mosaic structure in mountain ecosystems due to high terrain heterogeneity. This is confirmed by analysis of local sub-sets based on inter-serial correlation coefficients. Trees growing on stony slopes were gathered in one sub-set A at all three elevations. Splitting the local sample set into two sub-sets does not change the range of sensitivity, which indicates that for spruce in the study area this characteristic is independent from local conditions, as well.

The input of other small-scale factors, such as competition and social status of tree, was minimized in process of tree selection for sampling. Age and size effects were at least partially taken into account by standardization of TRW chronologies; besides, sub-sets don't have difference in age structure (Table 2). These facts also support our assumption about micro-conditions as main small-scale contributor to spruce growth patterns in the study area.

Synchronicity of the inter-annual oscillations in full and sub-set TRW chronologies within each site and positive significant correlations between them indicate the presence of an external signal common to both sub-sets, but varying with elevation, i.e. being climatic in nature. Nevertheless, the divergence between the sub-sets suggests that, for some climatic factors, the impact on spruce growth can be substantially transformed by micro-conditions. In this case, the dynamics of this divergence can also be an indicator of factors the response to which differs between sub-sets. In the light of this assumption it is interesting to find out what the divergence of growth trends may be due to, especially the strong one after 1980.

In some recent works, the local samples of conifers' individual TRW series were divided into sub-sets according to their response to climatic factors (Wilmking et al. 2004, 2005; Driscoll et al. 2005), which obtained a higher quality of resulting generalized chronologies. In our study, a reverse approach was proposed - classification into sub-sets by the criterion of the maximum common signal (inter-serial correlation), and the resulting chronologies have a significantly different climatic response. It would also be interesting in further research to test this classification against other methodological approaches to analyze of individual trees' growth patterns (cf. nonlinear models in Montoro Girona et al. 2017, classification by growth rate in Babushkina et al. 2015). This will provide better understanding of the factors involved in this divergence phenomenon.

\subsection{Climatic response of spruce}

The positive response of spruce growth to the temperature of the cold season and the precipitation of its first half is expressed in those trees that grow on steeper slopes with stony and less fertile soil (sub-sets A). In such conditions, the snow cover is set slowly, often slides down the slope and generally has a shallower depth than on flat terrain and especially in valleys. Rocky outcrops and stones also cool much faster than fertile soils. As a result of these combined factors, the soil freezes faster and deeper, and low 
winter temperatures can cause damage to the root system (especially fine roots), suppressing the growth of trees in the next season (Ruess et al. 1998; Groffman et al. 2001; Tierney et al. 2001; Weih and Karlsson 2002). Cold winters are also a stress factor for plants because they can cause physiological shock in the foliage, which adversely affects plant growth and development in the next season (Kullman 1993; Oleksyn et al. 1998; Wang et al. 2005). During the second half of the cold season, the amount of precipitation in the region decreases, and the snow cover already achieves a maximal depth possible for the given landscape. As a result, the positive influence of precipitation weakens.

For trees growing in more favorable micro-conditions (sub-sets B), the positive reaction to winter precipitation is less pronounced. On the other hand, possible negative response of growth to winter temperatures in these conditions is supported by findings described, for example, in Scandinavia (Mäkinen et al. 2000; Miina 2000; Helama and Sutinen 2016). Some researchers associate such a reaction with disturbances in the balance of carbohydrates due to the mild winter, and the subsequent loss of needles, which leads to a slow growth of earlywood in the next spring (Jonsson 1969; Skre and Nes 1996). However, evidence of the effect of mild winters on the balance of carbohydrates is contradictory. According to other data, an increase in winter temperatures may cause a decrease in the loss of carbohydrate reserves accumulated at the end of the past vegetative season, providing more active growth (Yuan and $\mathrm{Li}$ 1999; Cullen et al. 2001). Regardless of the possible mechanisms, the ambiguous effect of winter conditions on spruce growth is confirmed by comparing long periods with relatively severe (1951-1980) and mild winters (1981-2010): after an increase in winter temperatures, the positive response to them weakened, and the negative response intensified (Table 4). A similar dynamics of the spruce's climate response caused by climate change is found, for example, in northwest China (Lei et al. 2016).

Elevational patterns of spring-summer temperatures and precipitation influence on the spruce growth are typical for the mountain zonality of vegetation distribution. At the upper limit, the spruce distribution and growth are limited by a lack of heat, so a positive response to the temperature of the end of May and June is observed. The amount of spring-summer precipitation at this elevation is sufficient or even redundant in terrain depressions (HIGH B), which provides a neutral-negative response (Helama and Sutinen 2016; Yang et al. 2017). At the lower limit of the range, spruce, with its relatively high requirements for soil moisture, starts to suffer from its deficit before other conifers, which causes in May a positive correlation of growth with precipitation and a negative one with temperature as a regulator of soil moisture losses (Mäkinen et al. 2002; Babushkina et al. 2011; Lei et al. 2016; Chen et al. 2017). Consequently, in the center of the range with intermediate climatic conditions, the climatic response during the period of tree ring development is substantially dependent on micro-conditions; for example, a positive effect of May precipitation is observed only for trees growing on slopes (MID A). In addition to the direction of the response to climatic factors, the elevational gradient is also observed in its timing: the maximum response to temperatures shifts from mid-May (LOW) to mid-June (HIGH). Obviously, this pattern is caused by the elevational temperature gradient and the corresponding changes in the cambial activity period (Rossi et al. 2008, 2014; Begum et al. 2013; Kraus et al. 2016).

The question arises, why is the degree of spruce growth limitation by spring-summer temperature low even on its upper distribution limit in comparison to other studies of the upper and northern treeline? A possible cause of this phenomenon may be the sharply continental climate of the region, which is located practically in the center of Asia. Very large difference between summer and winter temperatures means that along the elevational lapse of temperature, frosty winters begin to limit tree growth earlier (i.e. at lower elevations) than the lack of heat during the growing season. As a result, the range of species simply does not reach a point of limitation by spring-summer temperatures. Indirect evidence for this assumption is that at the HIGH site, unlike the cold season, the warming trend of summer temperatures is not accompanied by a change in their influence on growth.

It should be noted that sensitive to the cold season's climate chronologies capture not only its annual fluctuations, but also long-term trends, as indicated by extremely high correlations observed between corresponding smoothed series. It is known that winter temperatures throughout all of Central Asia have a strong negative relationship with the Siberian High (Gong and Ho 2002). On the other hand, as shown in the same study, the relationships of winter precipitation with this anticyclone are ambiguous, uneven, and complicated by the impact of regional terrain and by the spatial heterogeneity of this climatic factor. Nevertheless, high correlations between long-term variation of cold season temperature and precipitation 
may indicate the negative influence of Siberian High in the study area on precipitation, as well. In this connection, it seems promising to study the possibilities of using the obtained chronologies of the Siberian spruce radial growth for the reconstruction of the dynamic of this center of atmospheric circulation which is clearly important to Asian continent.

Persistence of positive and negative responders' quantitative comparability along elevational gradient is reassuring in regards to stability of spruce distribution range (and thus to implications for forest management and preservation) in the face of climate change. It gives grounds to hope for survival or even prosperity of significant part of the spruce stand, provided by high small-scale diversity of landscape in mountains, under any direction of long-term climatic trends. This is in general agreement with observation of Körner (2009) about adaptation of plants to climate change in Alps: "small scale mosaic of life conditions commonly permits short distance escapes from what might become a too warm or too dry microhabitat". Human activity (reservoir building) forces some local climatic trends on the Borus Ridge to outpace regional climate change, therefore findings of this study portray rather optimistic precursor to the future behavior of spruce mountain forests in the rest of the region.

\section{Conclusion}

This study confirmed that in mountain forest ecosystems, micro-conditions significantly modify the climatic effect on the growth of conifers, particularly Siberian spruce, across the whole range of its distribution, leading to a divergence in growth trends and climatic responses. Main climate-growth relationships observed during growing season vary with elevation (shifting from negative to positive for temperature influence, and vice versa for precipitation) due to respective climatic gradients, as is expected for mountain forests. Classification of trees into sub-sets accordingly to growth patterns allowed us to obtain TRW chronologies of spruce having a strong response to the climatic conditions of the cold season. This is particularly important in light of the high rate of recent winter temperature increase in the region. These chronologies can be used to analyze and reconstruct both annual and long-term variation of the cold season temperatures and precipitation, and they also seem promising as possible indicators of the atmospheric circulation patterns in Central Asia.

\section{Acknowledgements}

Authors would like to thank administration of the National Park "Shushensky Bor" and personally its director Tolmachev V.A. for providing permission and facilitating field work on the park territory. Also, authors are grateful to the editor and reviewers for their constructive comments that have helped to improve this work significantly. The research reported in this manuscript is funded by the Russian Foundation for Basic Research (project no. 17-04-00315).

Electronic supplementary material: Supplementary material (Appendixes 1-4) is available in the online version of this article at https://doi.org/10.1007/s11629-018-4974-6.

\section{References}

Anderson RG, Goulden ML (2011) Relationships between climate, vegetation, and energy exchange across a mountain gradient. Journal of Geophysical Research: Biogeosciences, 116(G1). https://doi.org/10.1029/2010JGoo1476

Babushkina EA, Knorre AA, Vaganov EA, Bryukhanova MV (2011) Transformation of climatic response in radial increment of trees depending on topoecological conditions of their occurrence. Geography and Natural Resources, 32(1): 80-86. https://doi.org/10.1134/S1875372811010148

Babushkina EA, Vaganov EA, Belokopytova LV, et al. (2015) Competitive strength effect in the climate response of scots pine radial growth in south-central siberia forest-steppe. Tree Ring Research, 71(2): 106-117. https://doi.org/10.3959/1536-1098-71.2.106 
Barber VA, Juday GP, Finney BP (2000) Reduced growth of Alaskan white spruce in the twentieth century from temperature-induced drought stress. Nature 405(6787): 668. https://doi.org/10.1038/35015049

Becker A, Bugmann H (eds.) (2001) Global Change and Mountain Regions: the Mountain Research Initiative. IGBP Report 49, Stockholm. p. 48.

Becker A, Körner C, Brun JJ, et al. (2007) Ecological and land use studies along elevational gradients. Mountain Research and Development 27(1): 58-65. https://doi.org/10.1659/o276-4741(2007)27[58:EALUSA]2.0.CO;2

Begum S, Nakaba S, Yamagishi Y, et al. (2013) Regulation of cambial activity in relation to environmental conditions: understanding the role of temperature in wood formation of trees. Physiologia Plantarum 147(1): 46-54. https://doi.org/10.1111/j.13993054.2012.01663.x

Belokopytova LV, Babushkina EA, Zhirnova DF, et al. (2018) Climatic response of conifer radial growth in forest-steppes of South Siberia: comparison of three approaches. Contemporary Problems of Ecology 11(4):366-376. https://doi.org/10.1134/S1995425518040030

Briffa KR, Osborn TJ, Schweingruber FH (2004) Large-scale temperature inferences from tree rings: a review. Global and Planetary Change 40(1-2): 11-26. https://doi.org/10.1016/So921-8181(03)00095-X

Carrer M, Castagneri D, Prendin AL, Petit G, von Arx G (2017) Retrospective analysis of wood anatomical traits reveals a recent extension in tree cambial activity in two high-elevation conifers. Frontiers in Plant Science 8: 737. https://doi.org/10.3389/fpls.2017.00737

Case BS, Duncan RP (2014) A novel framework for disentangling the scale-dependent influences of abiotic factors on alpine treeline position. Ecography 37: 838-851. https://doi.org/10.1111/ecog.00280

Castagneri D, Fonti P, von Arx G, et al. (2017) How does climate influence xylem morphogenesis over the growing season? Insights from long-term intra-ring anatomy in Picea abies. Annals of Botany 119(6): 1011-1020. https://doi.org/10.1093/aob/mcw274

Chae H, Lee H, Lee S, et al. (2012) Local variability in temperature, humidity and radiation in the Baekdu Daegan Mountain protected area of Korea. Journal of Mountain Science 9(5): 613-627. https://doi.org/10.1007/s11629-012-2347-0

Chapman WL, Walsh JE (1993) Recent variations of sea ice and air temperature in high latitudes. Bulletin of the American Meteorological Society 74(1): 33-47. https://doi.org/10.1175/1520-0477(1993)074<0033:RVOSIA>2.0.CO;2

Chen F, Zhang RB, Wang HQ, et al. (2015) Recent climate warming of central China reflected by temperature-sensitive tree growth in the eastern Qinling Mountains and its linkages to the Pacific and Atlantic oceans. Journal of Mountain Science 12(2): 396-403 https://doi.org/10.1007/s11629-014-3196-9

Chen L, Huang JG, Stadt KJ, et al. (2017) Drought explains variation in the radial growth of white spruce in western Canada. Agricultural and forest meteorology 233: 133-142. https://doi.org/10.1016/j.agrformet.2016.11.012

Chhin S, Hogg ET, Lieffers VJ, et al. (2008) Potential effects of climate change on the growth of lodgepole pine across diameter size classes and ecological regions. Forest Ecology and Management 256(10): 1692-1703. https://doi.org/10.1016/j.foreco.2008.02.046

Cook ER (1985) A Time Series Analysis Approach to Tree-Ring Standardization. PhD Thesis, University of Arizona, Tucson. p. 171.

Cook ER, Kairiukstis LA (eds.) (1990) Methods of Dendrochronology. Application in Environmental Sciences. Kluwer Acad. Publ., Dordrecht; Boston; London. p. 394

Cook ER, Krusic PJ (2005) Program ARSTAN (Version 41d). (http://www.ldeo.columbia.edu/tree-ring-laboratory/resources/software, accessed on 2018-04-02)

Cullen LE, Palmer JG, Duncan RP, et al. (2001) Climate change and tree-ring relationships of Nothofagus menziesii tree-line forests. Canadian Journal of Forest Research 31: 1981-1991. https://doi.org/10.1139/x01-127

D’Arrigo R, Wilson R, Liepert B, et al. (2008) On the "Divergence Problem" in Northern Forests: A review of the tree-ring evidence and possible cases. Global and Planetary Change 60: 289-305. https://doi.org/10.1016/j.gloplacha.2007.03.004

Di Filippo A, Biondi F, Maugeri M, et al. (2012) Bioclimate and growth history affect beech lifespan in the Italian Alps and Apennines. Global Change Biology 18(3): 960-972. https://doi.org/10.1111/j.1365-2486.2011.02617.x

Di Filippo A, Pederson N, Baliva M, et al. (2015) The longevity of broadleaf deciduous trees in Northern Hemisphere temperate forests: insights from tree-ring series. Frontiers in Ecology and Evolution 3: 46. https://doi.org/10.3389/fevo.2015.00046

Driscoll WW, Wiles GC, D'Arrigo RD, et al. (2005) Divergent tree growth response to recent climatic warming, Lake Clark National Park and Preserve, Alaska. Geophysical Research Letters 32: L20703. https://doi.org/10.1029/2005 GL024258.

Fauquette S, Suc JP, Médail F, et al. (2018) The Alps: a geological, climatic and human perspective on vegetation history and modern plant diversity. In: Hoorn C, Perrigo A, Antonelli A (eds.) Mountains, Climate and Biodiversity. Wiley-Blackwell. pp. 413-428.

Gong DY, Ho CH (2002) The Siberian High and climate change over middle to high latitude Asia. Theoretical and Applied Climatology 72(1-2): 1-9. https://doi.org/10.1007/s007040200008

Gonzalez P, Neilson RP, Lenihan JM, et al. (2010) Global patterns in the vulnerability of ecosystems to vegetation shifts due to climate change. Global Ecology and Biogeography 19(6): 755-768. https://doi.org/10.1111/j.1466-8238.2010.00558.x

Gottfried M, Pauli H, Reiter K, et al. (1999) A fine-scaled predictive model for changes in species distribution patterns of high mountain plants induced by climate warming. Diversity and Distributions 5(6): 241-251. https://doi.org/10.1046/j.14724642.1999.00058.x

Gottfried M, Pauli H, Futschik A, et al. (2012) Continent-wide response of mountain vegetation to climate change. Nature Climate Change 2(2): 111. https://doi.org/10.1038/nclimate1329

Groffman PM, Driscoll CT, Fahey TJ, et al. (2001) Colder soils in a warmer world: a snow manipulation study in a northern hardwood forest ecosystem. Biogeochemistry 56(2): 135-150. https://doi.org/10.1023/A:1013039830323

Hamann A, Wang $\mathrm{T}$ (2006) Potential effects of climate change on ecosystem and tree species distribution in British Columbia. Ecology 87(11): 2773-2786. https://doi.org/10.1890/0012-9658(2006)87[2773:PEOCCO]2.0.CO;2

Hamlet AF, Lettenmaier DP (2005) Production of temporally consistent gridded precipitation and temperature fields for the continental United States. Journal of Hydrometeorology 6(3): 330-336. https://doi.org/10.1175/JHM420.1

Helama S, Sutinen R (2016) Inter-and intra-seasonal effects of temperature variation on radial growth of alpine treeline Norway spruce. Journal of Mountain Science 13(1): 1-12. https://doi.org/10.1007/s11629-015-3665-9

Holmes RL (1983) Computer-assisted quality control in tree-ring dating and measurement. Tree-Ring Bulletin 43: 68-78.

Jiang Y, Wang BQ, Dong MY, et al. (2015) Response of daily stem radial growth of Platycladus orientalis to environmental factors in a semi-arid area of North China. Trees 29(1): 87-96. https://doi.org/10.1007/s00468-014-1089-8

Jiao L, Jiang Y, Wang M, et al. (2016) Responses to climate change in radial growth of Picea schrenkiana along elevations of the eastern Tianshan Mountains, northwest China. Dendrochronologia 40: 117-127. https://doi.org/10.1016/j.dendro.2016. 09.002

Jochner M, Bugmann H, Nötzli M, Bigler C (2018) Tree growth responses to changing temperatures across space and time: a fine-scale analysis at the treeline in the Swiss Alps. Trees 32: 645-66o. https://doi.org/10.1007/so0468-017-1648-x

Jonsson B (1969) Studies of Variations in the Widths of Annual Rings in Scots Pine and Norway Spruce due to Weather Conditions in Sweden. Institutionen för Skogsproduktion, Stockholm. p 297. (In Swedish)

Kattsov VM, Semenov SM (eds.) (2014) Second Roshydromet Assessment Report on Climate Change and its Consequences in Russian Federation. Roshydromet, Moscow. p 54. (In Russian) 
Körner CH (1995) Alpine Plant Diversity: a Global Survey and Functional Interpretations. In: Chapin FS III, Körner C (eds.) Arctic and Alpine Biodiversity: Patterns, Causes and Ecosystem Consequences. Springer, Berlin, Heidelberg. pp. 45-62.

Körner C (2000) Why are there global gradients in species richness? Mountains might hold the answer. Trends in Ecology \& Evolution 15(12): 513-514. https://doi.org/10.1016/So169-5347(00)02004-8

Körner C (2003) Alpine Plant Life: Functional Plant Ecology of High Mountain Ecosystems. Springer Science \& Business Media. p. 344.

Körner C (2007) The use of 'altitude' in ecological research. Trends in ecology \& evolution 22(11): 569-574. https://doi.org/10.1016/j.tree.2007.09.006

Körner C (2009) Mountain Vegetation under Environmental Change. In: Jandl R, Borsdorf A, Miegroet HV, Lackner R, Psenner R (eds.) Global Change and Sustainable Development in Mountain Regions. Innsbruck University Press, Innsbruck. pp. 25-29.

Körner C (2016) Plant adaptation to cold climates. F10ooResearch 5 (F10oo Faculty Rev): 2769. https://doi.org/10.12688/f10oo research.9107.1

Kosmakov IV (2001) Thermal and Ice Regime in the Upper and Lower Reaches of High-Pressure Hydroelectric Power Stations on the Yenisei. Klaretianum, Krasnoyarsk. p 142. (In Russian)

Kraus C, Zang C, Menzel A (2016) Elevational response in leaf and xylem phenology reveals different prolongation of growing period of common beech and Norway spruce under warming conditions in the Bavarian Alps. European Journal of Forest Research 135(6): 1011-1023. https://doi.org/10.1007/s10342-016-0990-7

Kug JS, Jeong JH, Jang YS, et al. (2015) Two distinct influences of Arctic warming on cold winters over North America and East Asia. Nature Geoscience 8(10): 759. https://doi.org/10.1038/ngeo2517

Kulagin AY, Davydychev AN, Zaitsev GA (2006) Specific features of the growth of Siberian spruce (Picea obovata Ledeb.) at early stages of ontogeny in broadleaf-conifer forests of the Ufa plateau. Russian Journal of Ecology 37(1): 66-69. https://doi.org/10.1134/S1067413606010115

Kullman L (1993) Tree limit dynamics of Betula pubescens ssp. tortuosa in relation to climate variability: evidence from central Sweden. Journal of Vegetation Science 4(6): 765-772. https://doi.org/10.2307/3235613

Lange J, Cruz-García R, Gurskaya M, et al. (2016). Can microsite effects explain divergent growth in treeline Scots pine? In: TRACE Tree Rings in Archaeology, Climatology and Ecology, Volume 14. Scientific Technical Report 16/04, GFZ German Research Centre for Geosciences. pp. 93-101. https://doi.org/10.2312/GFZ.b103-16042

Latreille A, Davi H, Huard F, et al. (2017) Variability of the climate-radial growth relationship among Abies alba trees and populations along altitudinal gradients. Forest Ecology and Management 396: 150-159. https://doi.org/10.1016/j.foreco.2017.04.012

Lei JP, Feng XH, Shi Z, et al. (2016) Climate-growth relationship stability of Picea crassifolia on an elevation gradient, Qilian Mountain, Northwest China. Journal of Mountain Science 13(4): 734-743. https://doi.org/10.1007/s11629-015-3784-3

Li Y, Zhang CQ, Zhou XH (2014) Ecological responses to Holocene millennial-scale climate change at high altitudes of East and Central Asia: A case study of Picea/Abies pollen changes in lacustrine sediments. Journal of Mountain Science 11(3): 674-687. https://doi.org/10.1007/s11629-014-2980-x

Lo, YH, Blanco JA, Seely B, et al. (2010) Relationships between climate and tree radial growth in interior British Columbia, Canada. Forest Ecology and Management 259(5): 932-942. https://doi.org/10.1016/j.foreco.2009.11.033

Lyu L, Deng X, Zhang QB (2016) Elevation pattern in growth coherency on the southeastern Tibetan Plateau. PloS one, 11(9): e0163201. https://doi.org/10.1371/journal.pone.0163201

Mäkinen H, Nöjd P, Mielikäinen K (2000) Climatic signal in annual growth variation of Norway spruce (Picea abies) along a transect from central Finland to the Arctic timberline. Canadian Journal of Forest Research 30: 769-777. https://doi.org/10.1139/xo0-005

Mäkinen H, Nöjd P, Kahle HP, et al. (2002) Radial growth variation of Norway spruce (Picea abies (L.) Karst.) across latitudinal and altitudinal gradients in central and northern Europe. Forest Ecology and Management 171(3): 243-259. https://doi.org/10.1016/So378-1127(01)00786-1

Maurer EP, Wood AW, Adam JC, et al. (2002) A long-term hydrologically based dataset of land surface fluxes and states for the conterminous United States. Journal of Climate 15(22): 3237-3251. https://doi.org/10.1175/15200442(2002)015<3237:ALTHBD>2.0.CO;2

Miina J (2000) Dependence of tree-ring, earlywood and latewood indices of Scots pine and Norway spruce on climatic factors in eastern Finland. Ecological Modelling 132: 259-273. https://doi.org/10.1016/so304-3800(o0)o0296-9

Monnier Y, Prévosto B, Ripert C, et al. (2012) Forest microhabitats differentially influence seedling phenology of two co-existing Mediterranean oak species. Journal of Vegetation Science 23(2): 260-270. https://doi.org/10.1111/j.1654-1103.2011.01358.x

Montoro Girona M, Morin H, Lussier JM, et al. (2016) Radial growth response of black spruce stands ten years after experimental shelterwoods and seed-tree cuttings in boreal forest. Forests 7: 240. https://doi.org/10.3390/f7100240

Montoro Girona M, Rossi S, Lussier JM, et al. (2017). Understanding tree growth responses after partial cuttings: A new approach. PLoS ONE 12: e0172653. https://doi.org/10.1371/journal.pone.0172653

Müller M, Schickhoff U, Scholten T, et al. (2016) How do soil properties affect alpine treelines? General principles in a global perspective and novel findings from Rolwaling Himal, Nepal. Progress in Physical Geography 40: 135-160. https://doi.org/10.1177/0309133315615802

Naurzbaev MM, Vaganov EA (2000) Variation of early summer and annual temperature in east Taymir and Putoran (Siberia) over the last two millennia inferred from tree rings. Journal of Geophysical Research: Atmosphere 105(D6): 7317-7326. https://doi.org/10.1029/1999JD901059

Oleksyn J, Tjoelker MG, Reich PB (1998) Adaptation to changing environment in Scots pine populations across a latitudinal gradient. Silva Fennica 32(2): 129-140. https://doi.org/10.14214/sf.691

Popov AV, Shatravskii AI (1994) Removal of floating timber from the Sayano-Shushenskoe hydrostation reservoir. Hydrotechnical Construction 28: 204. https://doi.org/10.1007/BF01545054

Rinntech (2011). LINTAB: Precision Ring by Ring. (http://www.rinntech.de/content/view/16/47/lang,english/, accessed on 2018-0402)

Rogers JC, Mosely-Thompson E (1995). Atlantic Arctic cyclones and mild Siberian winters of the 1980s. Geophysical Research Letters 22: 799-802. https://doi.org/10.1029/95GL00301

Rossi S, Deslauriers A, Griçar J, et al. (2008) Critical temperatures for xylogenesis in conifers of cold climates. Global Ecology and Biogeography 17(6): 696-707. https://doi.org/10.1111/j.1466-8238.2008.00417.x

Rossi S, Girard M-J, Morin H (2014) Lengthening of the duration of xylogenesis engenders disproportionate increases in xylem production. Global Change Biology 20: 2261-2271. https://doi.org/10.1111/gcb.12470

Ruess RW, Hendrick RL, Bryant JP (1998) Regulation of fine root dynamics by mammalian browsers in early successional Alaskan taiga forests. Ecology 79(8): 2706-2720. https://doi.org/10.1890/0012-9658(1998)079[2706:ROFRDB]2.0.CO;2

Rumpf SB, Hülber K, Klonner G, et al. (2018) Range dynamics of mountain plants decrease with elevation. Proceedings of the National Academy of Sciences 115(8): 1848-1853. https://doi.org/10.1073/pnas.1713936115

Sang W (2009) Plant diversity patterns and their relationships with soil and climatic factors along an altitudinal gradient in the middle Tianshan Mountain area, Xinjiang, China. Ecological Research 24(2): 303-314. https://doi.org/10.1007/s11284-008-0507-z 
Savelieva NI, Semiletov IP, Vasilevskaya LN, Pugach SP (2000) A climate shift in seasonal values of meteorological and hydrological parameters for Northeastern Asia. Progress in Oceanography 47(2-4): 279-297. https://doi.org/10.1016/Soo79-6611(oo)ooo39-2

Savva Y, Oleksyn J, Reich PB, et al. (2006). Interannual growth response of Norway spruce to climate along an altitudinal gradient in the Tatra Mountains, Poland. Trees 20(6): 735-746. https://doi.org/10.1007/soo468-006-0088-9

Shiyatov SG (1986) Dendrochronology of the Higher Timberline on the Urals. Moskow: Nauka. p. 136. (In Russian).

Sidor CG, Popa I, Vlad R, Cherubini P (2015) Different tree-ring responses of Norway spruce to air temperature across an altitudinal gradient in the Eastern Carpathians (Romania). Trees 29(4): 985-997. https://doi.org/10.1007/so0468-015-1178-3

Skre O, Nes K (1996) Combined effects of elevated winter temperatures and $\mathrm{CO}_{2}$ on Norway spruce seedlings. Silva Fennica 30: 135143. https://doi.org/10.14214/sf.a9226

Subedi SC, Bhattarai KR, Chauudhary RP (2015) Distribution pattern of vascular plant species of mountains in Nepal and their fate against global warming. Journal of Mountain Science 12(6): 1345-1354. https://doi.org/10.1007/s11629-015-3495-9

Tierney GL, Fahey TJ, Groffman PM, et al. (2001) Soil freezing alters fine root dynamics in a northern hardwood forest. Biogeochemistry 56(2): 175-190. https://doi.org/10.1023/A:1013072519889

Tognetti R, Palombo C (2013) Take a tree to the limit: the stress line. Tree Physiology 33(9): 887-890. https://doi.org/10.1093/treephys/tpto87

Vaganov EA, Hughes MK, Shashkin AV (2006) Growth Dynamics of Conifer Tree Rings: Images of Past and Future Environments. Springer-Verlag, Berlin; New York. p. 354.

Vitasse Y, Delzon S, Bresson CC, et al. (2009) Altitudinal differentiation in growth and phenology among populations of temperatezone tree species growing in a common garden. Canadian Journal of Forest Research 39(7): 1259-1269. https://doi.org/10.1139/X09-054

Wang T, Ren H, Ma K (2005) Climatic signals in tree ring of Picea schrenkiana along an altitudinal gradient in the central Tianshan Mountains, northwestern China. Trees 19(6): 736-742. https://doi.org/10.1007/s00468-005-0003-9

Wang Z, Yang B, Deslauriers A, Bräuning A (2015) Intra-annual stem radial increment response of Qilian juniper to temperature and precipitation along an altitudinal gradient in northwestern China. Trees 29(1): 25-34. https://doi.org/10.1007/s00468-014-1037-7

Weih M, Karlsson PS (2002) Low winter soil temperature affects summertime nutrient uptake capacity and growth rate of mountain birch seedlings in the subarctic, Swedish lapland. Arctic, Antarctic, and Alpine Research, 434-439. https://doi.org/10.2307/1552201

Wieser G, Holtmeier FK, Smith WK (2014) Treelines in a Changing Global Environment. In: Tausz M, Grulke N (eds.), Trees in a Changing Environment. Springer, Dordrecht. pp 221-263. https://doi.org/10.1007/978-94-017-9100-7_10

Wilmking M, Juday GP, Barber VA, Zald HS (2004) Recent climate warming forces contrasting growth responses of white spruce at treeline in Alaska through temperature thresholds. Global Change Biology 10(10): 1724-1736. https://doi.org/10.1111/j.13652486.2004.00826.x

Wilmking M, D'arrigo R, Jacoby GC, et al. (2005) Increased temperature sensitivity and divergent growth trends in circumpolar boreal forests. Geophysical Research Letters 32: L15715. https://doi.org/10.1029/2005GL023331

WMO (2007) The role of climatological normals in a changing climate. World Meteorological Organization, Geneva. p 24.

Wypych A, Ustrnul Z, Schmatz DR (2018) Long-term variability of air temperature and precipitation conditions in the Polish Carpathians. Journal of Mountain Science 15(2): 237-253. https://doi.org/10.1007/s11629-017-4374-3

$\mathrm{Xu}$ M, Ma L, Jia Y, et al. (2017) Integrating the effects of latitude and altitude on the spatial differentiation of plant community diversity in a mountainous ecosystem in China. PloS one 12(3): e0174231. https://doi.org/10.1371/journal.pone.0174231

Yang B, He M, Shishov V, et al. (2017) New perspective on spring vegetation phenology and global climate change based on Tibetan Plateau tree-ring data. Proceedings of the National Academy of Sciences 114(27): 6966-6971. https://doi.org/10.1073/pnas.1616608114

Yuan Y, Li J (1999) Reconstruction and analysis of 450 years's winter temperature series in the Urumqi river source of Tianshan Mountains. Journal of Glaciology and Geocryology 21: 64-70. (In Chinese).

Zhang L, Jiang Y, Zhao S, et al. (2016) Different responses of the radial growth of conifer species to increasing temperature along altitude gradient: Pinus tabulaeformis in the Helan Mountains (Northwestern China). Polish Journal of Ecology 64(4): 509-525. https://doi.org/10.3161/15052249PJE2016.64.4.006

Ziaco E, Biondi F (2016) Tree growth, cambial phenology, and wood anatomy of limber pine at a Great Basin (USA) mountain observatory. Trees 30(5): 1507-1521. https://doi.org/10.1007/s00468-016-1384-7 

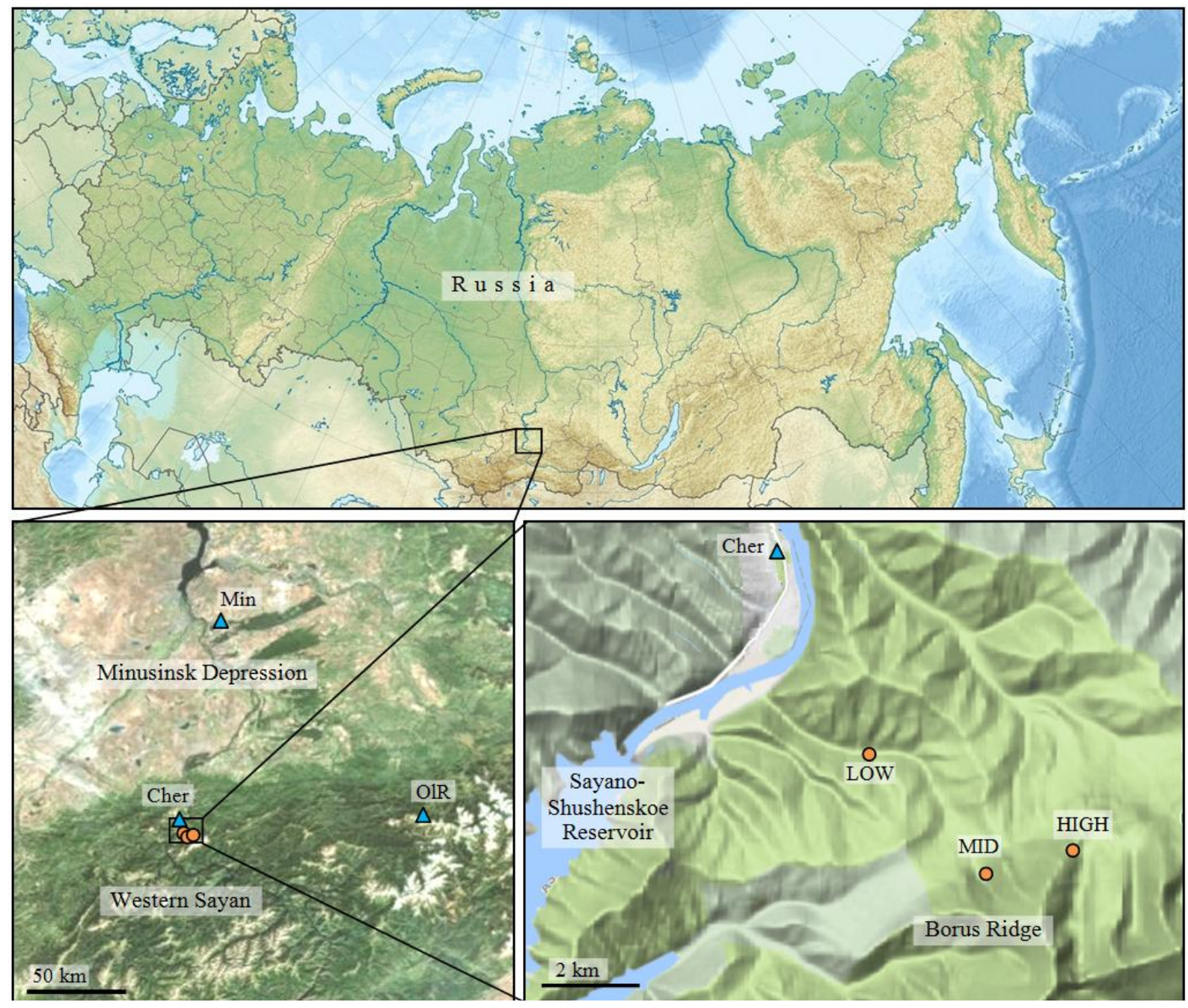

Figure 1 Study area. Triangles represent weather stations; circles represent sampling sites. 
(a) Elevational interpolation scheme

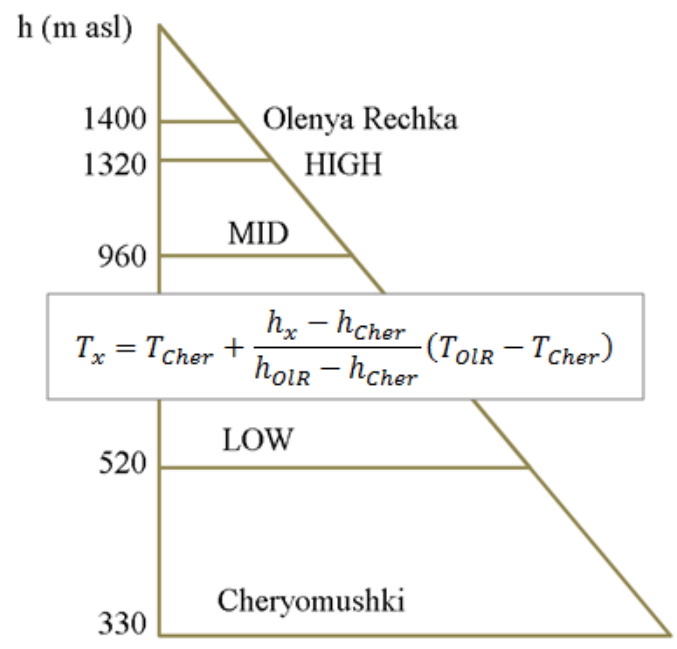

7 (c) $\mathrm{MID}$

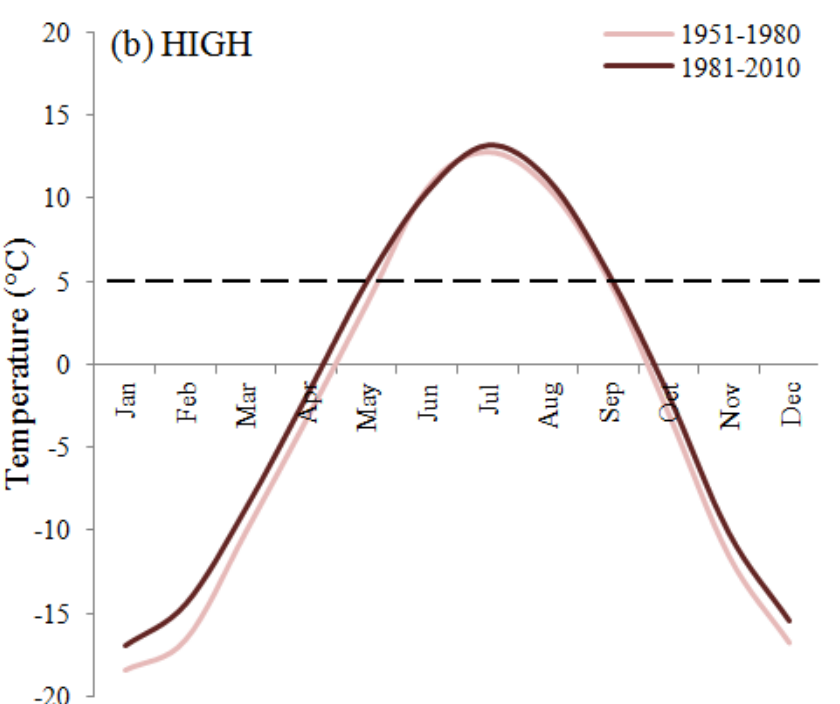

(d) LOW
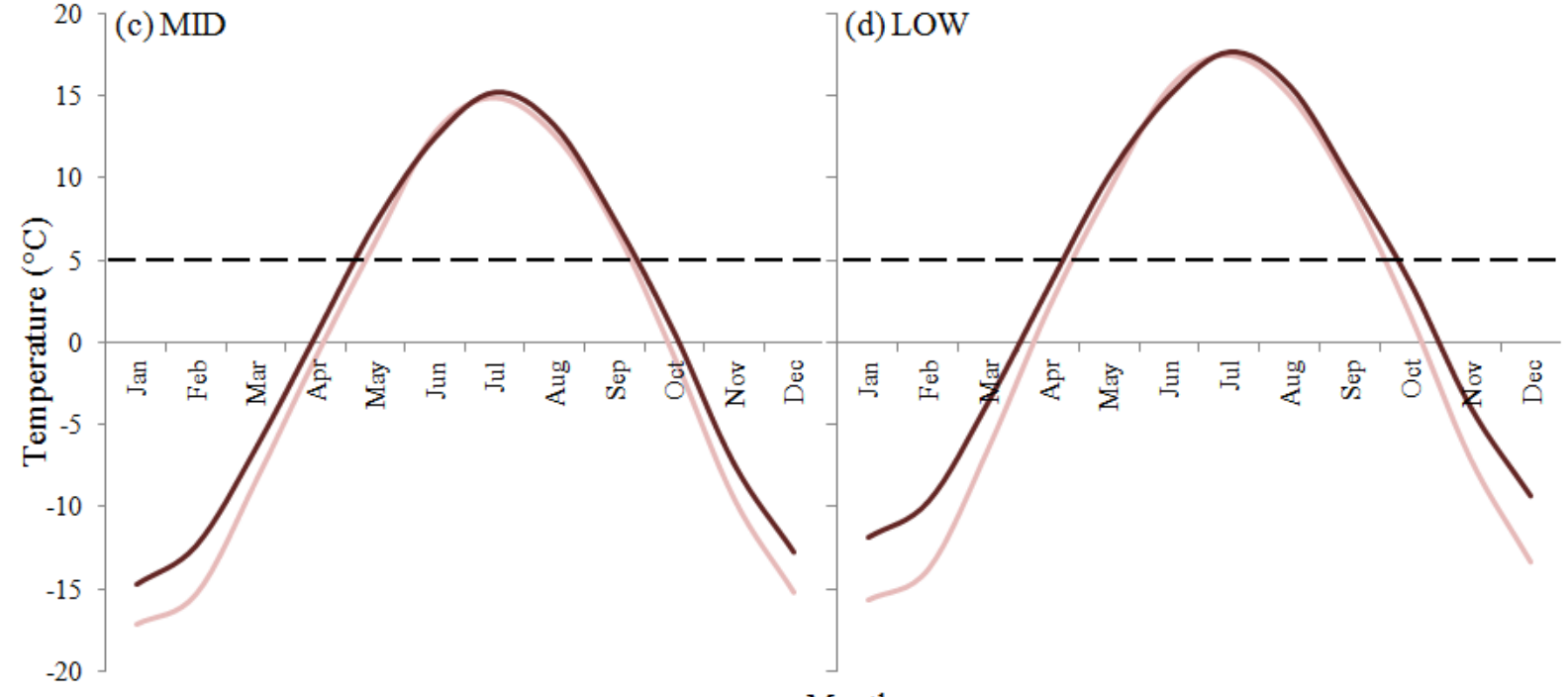

Months

Figure 2 Average intra-annual temperature dynamic interpolated from Cheryomushki and Olenya Rechka monthly series (a) for HIGH (b), MID (c) and LOW (d) sampling sites over 1951-1980 and 1981-2010 sub-periods. Dashed line represents $5^{\circ} \mathrm{C}$ temperature threshold of vegetative season.

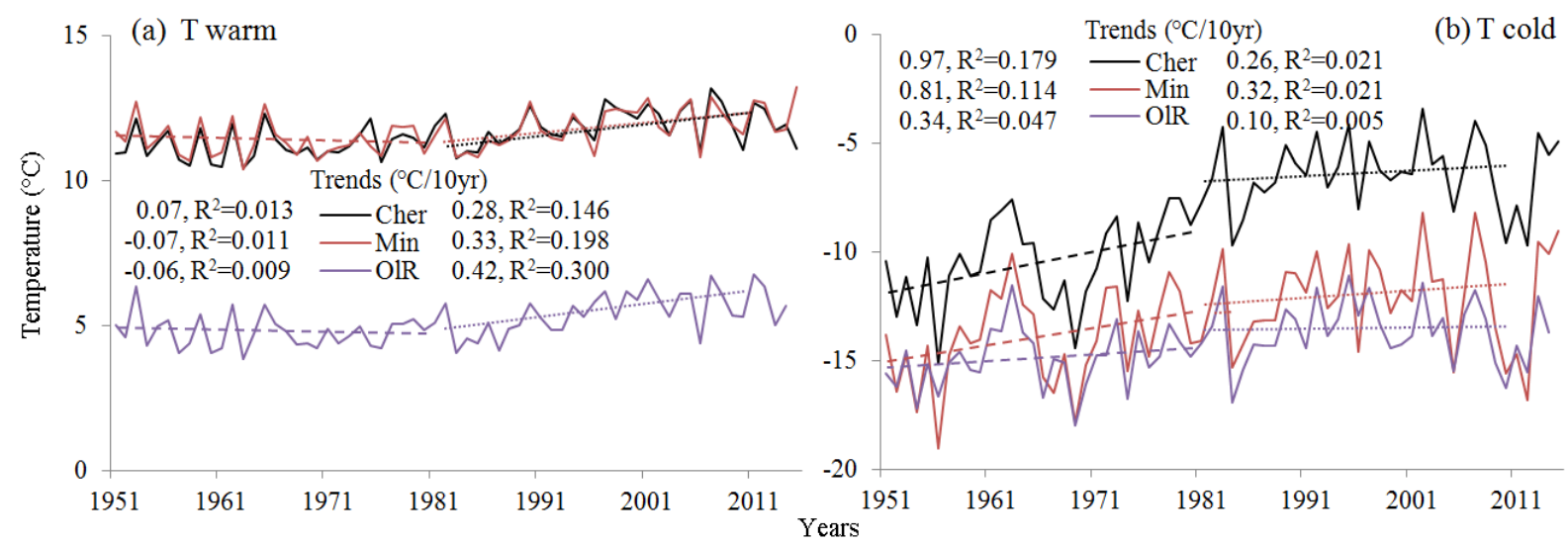

Figure 3 Inter-annual dynamic of April-October (a) and November-March (b) temperatures at weather stations Minusinsk (Min), Cheryomushki (Cher) and Olenya Rechka (OlR). Straight lines represent linear trends calculated for 1950-1980 and 1981-2010 sub-periods separately; trend slope and $\mathrm{R}^{2}$ values are given in legend. 


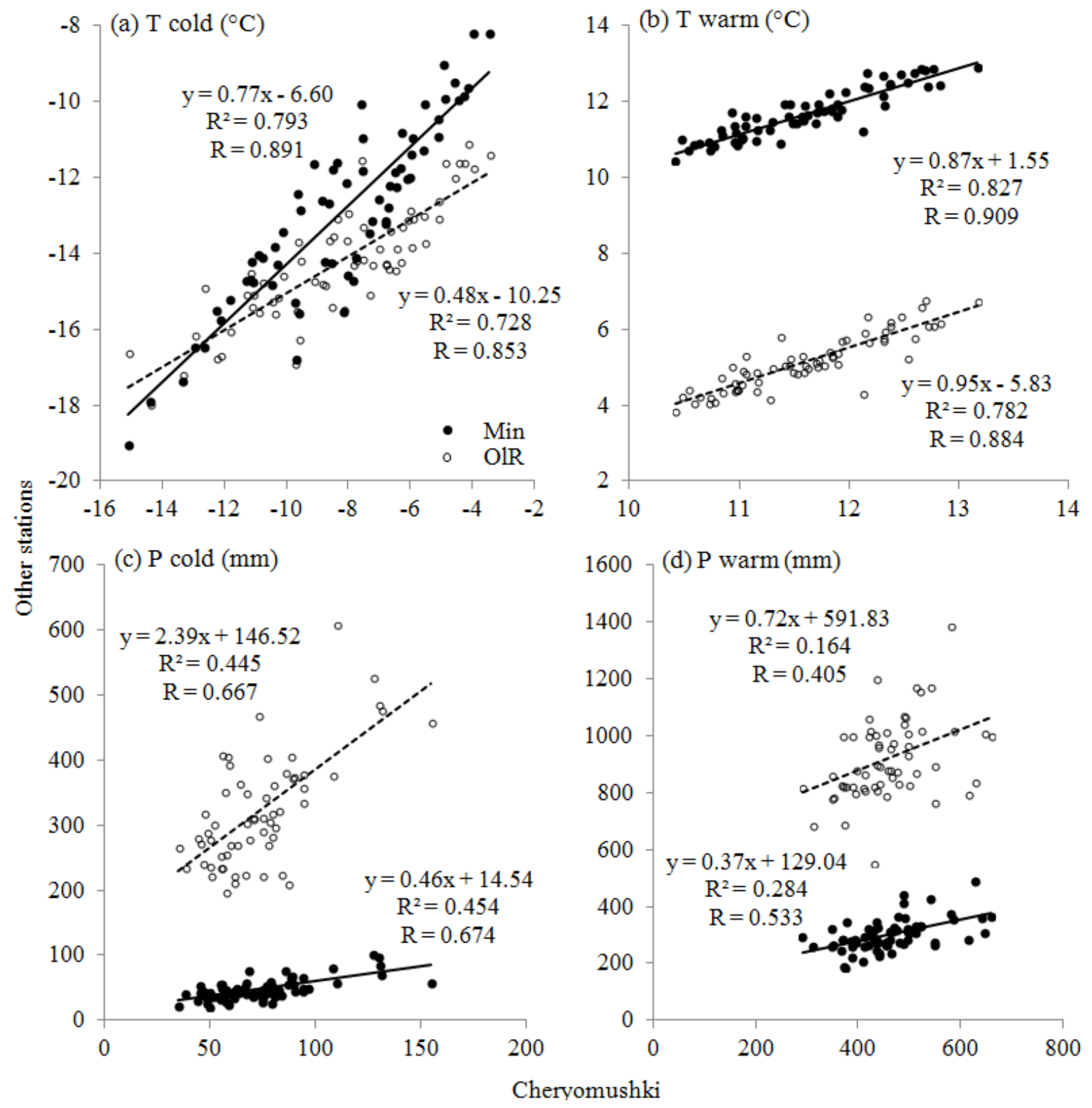

Figure 4 Relationships of Cheryomushki weather station climatic series of cold (November-March) and warm (AprilOctober) seasons with corresponding series from Minusinsk and Olenya Rechka stations over 1951-2015 period: mean temperatures $(a, b)$, sum of precipitation $(c, d)$. 


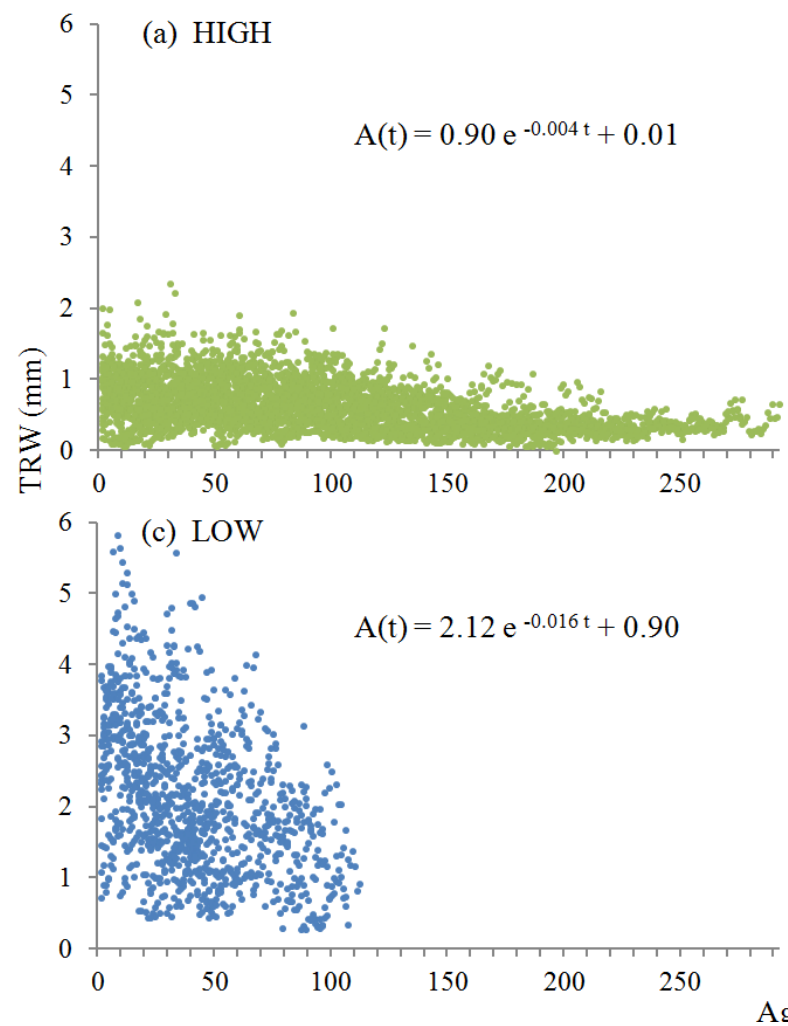

(b) MID

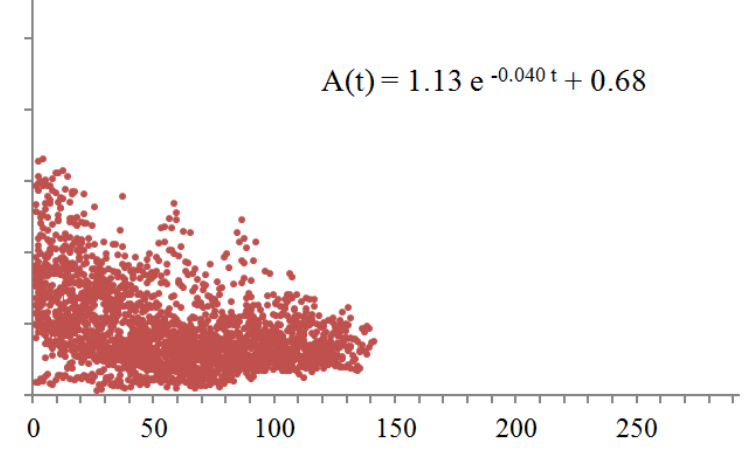

(d) Age curves

LOW $95 \%$

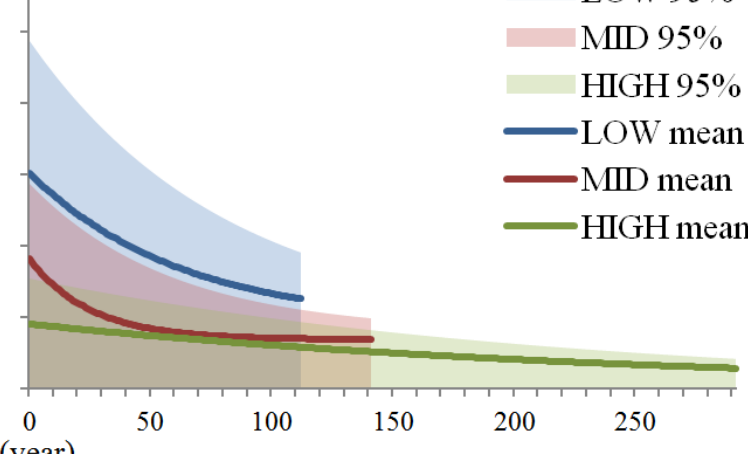

Figure 5 Age trends in TRW of Picea obovata: age-aligned individual TRW measurements for HIGH (a), MID (b), and LOW (c) sites, and comparison of fitted mean (lines) and 95 percentile (shades) exponential age curves for full samples at each site $(d)$.

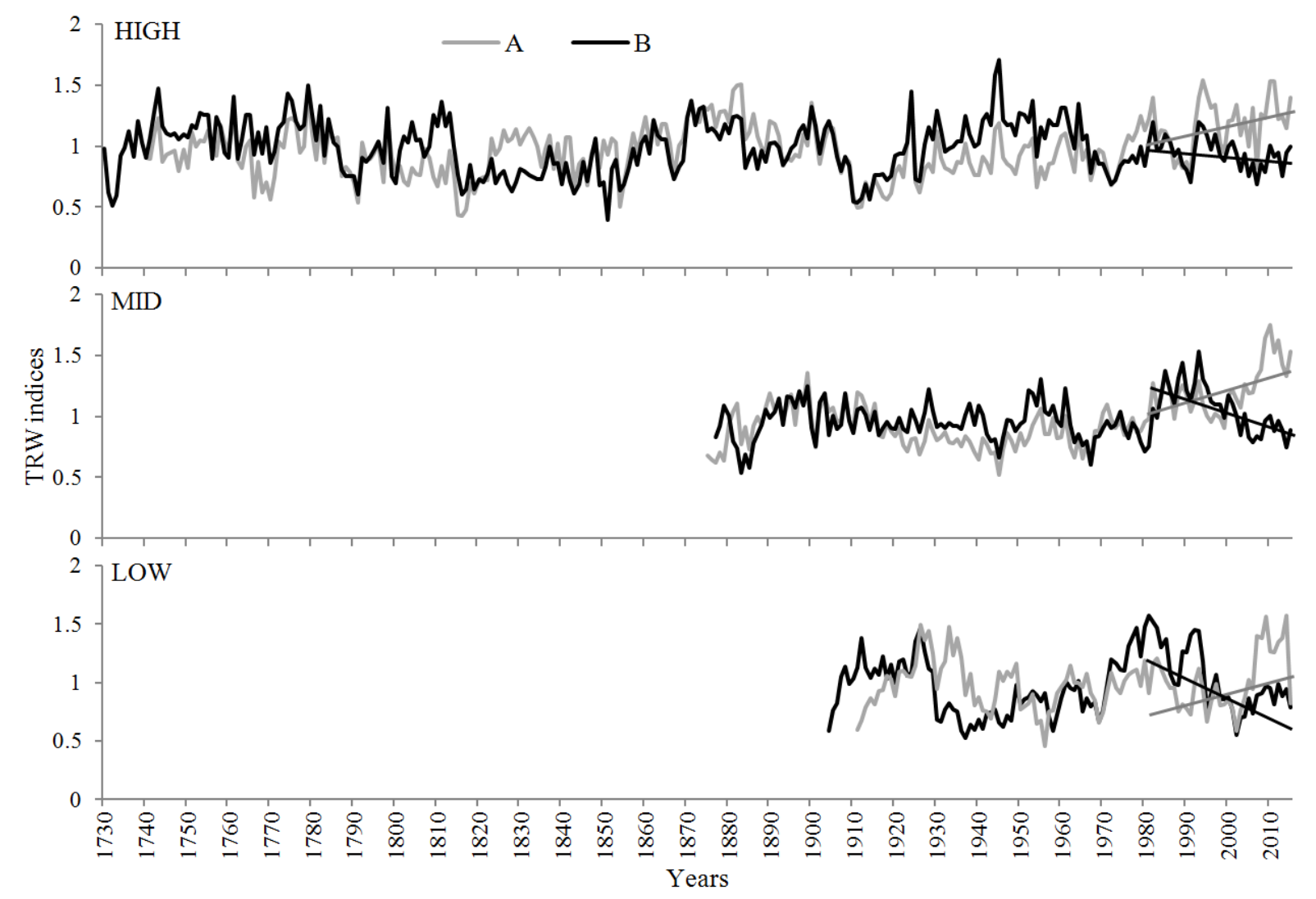

Figure 6 Time plots of standard indexed TRW chronologies. Straight lines are linear trends fitted since 1981. 

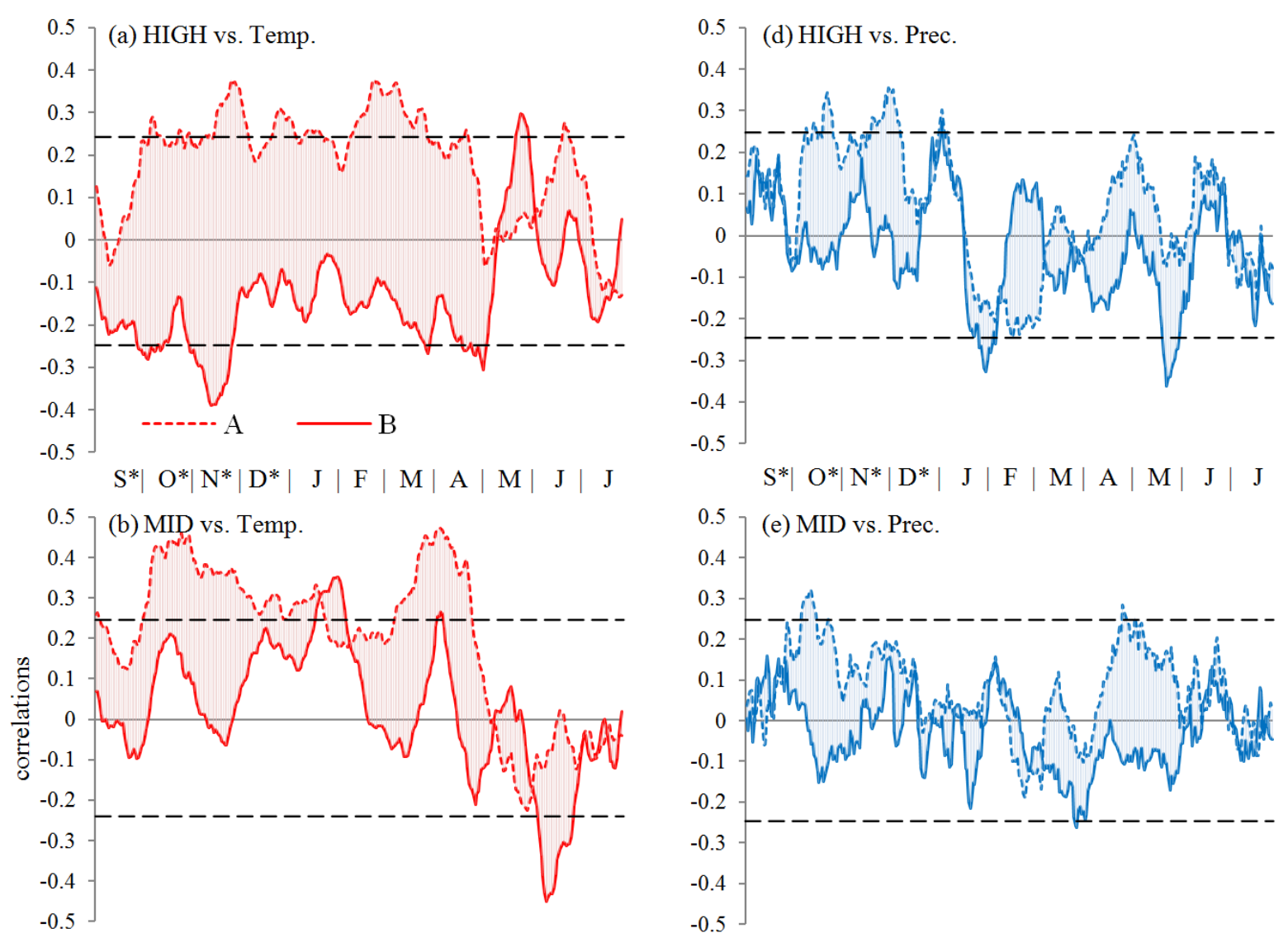

$\mathrm{S}^{*} \mathrm{O}^{*} \mathrm{~N}^{*}\left|\mathrm{D}^{*}\right| \mathrm{J}|\mathrm{F}| \mathrm{M}|\mathrm{A}| \mathrm{M}|\mathrm{J}| \mathrm{J}$
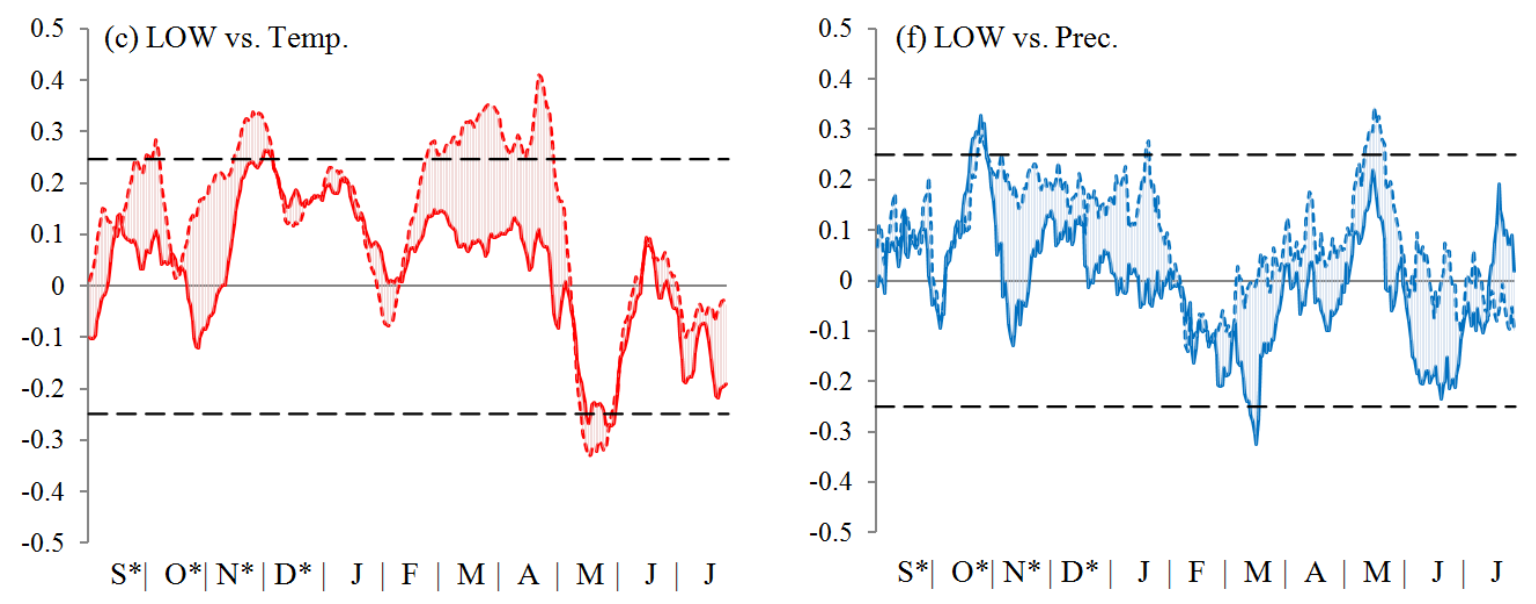

Months

Figure 7 Correlations of sub-set standard TRW chronologies with temperature (a-c) and precipitation (d-f) moving series (21-day window, 1-day step) from previous September to current July. Outside of these months, correlations are insignificant for all chronologies. Months of the previous year are marked with an asterisk $(*)$. Shades show differences between climatic responses of sub-sets A and B. Black dashed lines show significance level p = 0.05. 


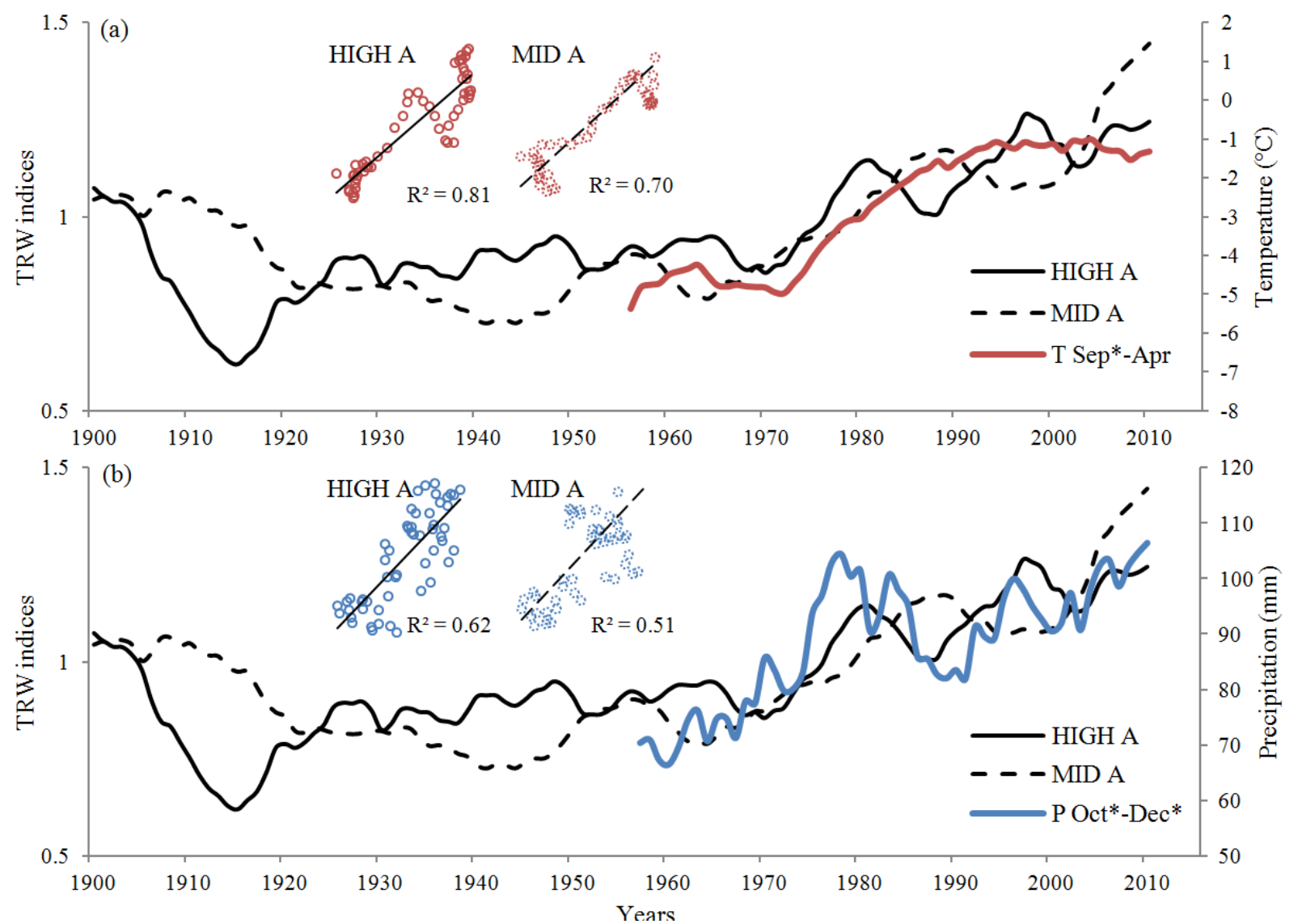

Figure 8 Low-frequency components (series smoothed by 11-year centered moving average): comparison of September-April temperatures (a) and October-December precipitation (b) with the most sensitive to them sub-set chronologies (HIGH A and MID A). Inserted frames show actual scatter plots and fitted linear regressions of respective climate-growth relationships. 
Table 1 Weather stations and their climatic characteristics.

\begin{tabular}{|c|c|c|c|c|c|c|c|c|c|}
\hline \multirow{3}{*}{ Station } & \multirow{2}{*}{\multicolumn{3}{|c|}{ Coordinates }} & \multicolumn{6}{|c|}{$\begin{array}{l}\text { Average climatic variables for } 1951-1980 \text { and } 1981-2010 \text { periods } \\
\text { (numerator and denominator, respectively) }\end{array}$} \\
\hline & & & & \multicolumn{3}{|c|}{ Mean temperature, $\mathrm{T}\left({ }^{\circ} \mathrm{C}\right)$} & \multicolumn{3}{|c|}{ Precipitation, $\mathrm{P}(\mathrm{mm})$} \\
\hline & $\mathrm{N}$ & $\mathrm{E}$ & $\begin{array}{c}\mathrm{h} \\
(\mathrm{m} \text { asl })\end{array}$ & Nov-Mar & Apr-Oct & year & Nov-Mar & Apr-Oct & year \\
\hline $\begin{array}{l}\text { Cheryomushki } \\
\text { (Cher) }\end{array}$ & $\begin{array}{c}52.87 \\
\circ\end{array}$ & $91.42^{\circ}$ & 330 & $\frac{-10.5 \pm 2.0}{-6.4 \pm 1.6}$ & $\frac{11.2 \pm 0.53}{11.9 \pm 0.6}$ & $\frac{2.1 \pm 0.9}{4.3 \pm 0.9}$ & $\frac{73 \pm 21}{75 \pm 27}$ & $\frac{447 \pm 86}{464 \pm 74}$ & $\frac{519 \pm 92}{539 \pm 78}$ \\
\hline $\begin{array}{l}\text { Minusinsk } \\
\text { (Min) }\end{array}$ & $\begin{array}{c}53.70 \\
\circ\end{array}$ & $91.70^{\circ}$ & 250 & $\frac{-14.1 \pm 2.1}{-12.1 \pm 2.0}$ & $\frac{11.4 \pm 0.6}{11.8 \pm 0.7}$ & $\frac{0.8 \pm 0.9}{1.9 \pm 1.0}$ & $\frac{49 \pm 19}{48 \pm 14}$ & $\frac{290 \pm 59}{314 \pm 56}$ & $\begin{array}{l}339 \pm 63 \\
362 \pm 60\end{array}$ \\
\hline $\begin{array}{l}\text { Olenya Rechka } \\
\text { (OlR) }\end{array}$ & $\begin{array}{c}52.80 \\
\circ\end{array}$ & $\underset{0}{93.23}$ & 1400 & $\frac{-15.0 \pm 1.4}{-13.9 \pm 1.3}$ & $\frac{4.8 \pm 0.6}{5.4 \pm 0.7}$ & $\begin{array}{l}-3.5 \pm 0.7 \\
-2.6 \pm 0.8\end{array}$ & $\begin{array}{r}322 \pm 71 \\
325 \pm 98\end{array}$ & $\frac{930 \pm 142}{911 \pm 148}$ & $\frac{1252 \pm 156}{1236 \pm 181}$ \\
\hline
\end{tabular}

Mean \pm standard deviation are calculated for months with negative (Nov-Mar) and positive (Apr-Oct) temperatures, which were estimated from Cheryomushki station data. Significant at $\mathrm{p}<0.05$ differences between mean values for 1951-1980 and 1981-2010 periods are bold.

Table 2 Main statistics of the TRW chronologies.

\begin{tabular}{|c|c|c|c|c|c|c|c|c|c|}
\hline \multirow{2}{*}{$\begin{array}{l}\text { Statistic } \\
\text { characteristics }\end{array}$} & \multicolumn{9}{|c|}{ Chronology } \\
\hline & LOW & LOW A & LOW B & MID & MID A & MID B & HIGH & HIGH A & HIGH B \\
\hline \multicolumn{10}{|c|}{ General } \\
\hline Time span, years & $\begin{array}{l}1904- \\
2015\end{array}$ & $\begin{array}{l}1911- \\
2015\end{array}$ & $\begin{array}{c}1904^{-} \\
2015\end{array}$ & $\begin{array}{l}1875^{-} \\
2015\end{array}$ & $\begin{array}{l}1875^{-} \\
2015\end{array}$ & $\begin{array}{l}1877^{-} \\
2015\end{array}$ & $\begin{array}{l}1724^{-} \\
2015\end{array}$ & $\begin{array}{l}1740- \\
2015\end{array}$ & $\begin{array}{l}1724^{-} \\
2015\end{array}$ \\
\hline Length, years & 112 & 105 & 112 & 141 & 141 & 139 & 292 & 276 & 292 \\
\hline Number of trees & 28 & 11 & 16 & 41 & 24 & 16 & 38 & 15 & 23 \\
\hline Age (min-max), years & $39-112$ & $39-103$ & $47-112$ & $36-141$ & $36-141$ & $36-139$ & $73-292$ & $73-276$ & $73-292$ \\
\hline Average age, years & 72 & 60 & 83 & 111 & 95 & 100 & 170 & 157 & 140 \\
\hline $\begin{array}{l}\text { Mean of trees (min- } \\
\text { max), mm }\end{array}$ & $\begin{array}{l}1.12- \\
3.98\end{array}$ & $1.12-3.01$ & $\begin{array}{l}1.37- \\
3.98\end{array}$ & $\begin{array}{c}0.23^{-} \\
1.77\end{array}$ & $\begin{array}{l}0.41- \\
1.66\end{array}$ & $\begin{array}{c}0.23^{-} \\
1.77\end{array}$ & $\begin{array}{c}0.38- \\
1.13\end{array}$ & $0.38-1.11$ & $0.42-1.11$ \\
\hline $\begin{array}{l}\text { Average mean TRW } \\
\text { for set of trees, mm }\end{array}$ & 2.25 & 2.36 & 2.09 & 0.99 & 0.95 & 1.02 & 0.72 & 0.67 & 0.76 \\
\hline \multicolumn{10}{|c|}{ Standard indexed chronologies } \\
\hline Standard deviation & 0.202 & 0.226 & 0.254 & 0.170 & 0.224 & 0.168 & 0.187 & 0.221 & 0.211 \\
\hline $\begin{array}{l}\text { Mean inter-serial } \\
\text { correlation* }\end{array}$ & 0.265 & 0.405 & 0.430 & 0.240 & 0.351 & 0.329 & 0.272 & 0.291 & 0.396 \\
\hline Signal-to-noise ratio & 10.1 & $7 \cdot 5$ & 12.1 & 12.9 & 13.0 & 7.8 & 14.2 & 6.2 & 15.1 \\
\hline Mean sensitivity & 0.139 & 0.140 & 0.125 & 0.119 & 0.126 & 0.124 & 0.140 & 0.160 & 0.142 \\
\hline $\begin{array}{l}\text { First-order } \\
\text { autocorrelation }\end{array}$ & 0.752 & 0.688 & 0.830 & 0.656 & 0.770 & 0.640 & 0.564 & 0.621 & 0.648 \\
\hline
\end{tabular}

* Mean inter-serial correlation calculated with 50-year window and 1-year step.

Table 3 Correlations between sub-set standard TRW chronologies during their common period (1911-2015).

\begin{tabular}{|c|c|c|c|c|c|c|}
\hline $\begin{array}{c}\text { Chrono- } \\
\text { logy }\end{array}$ & LOW & LOW & MID & MID & HIGH & HIGH \\
\hline LOW A & & $\mathbf{0 . 2 2}$ & A & B & A & B \\
\hline LOW B & $\mathbf{0 . 2 2}$ & & $\mathbf{- 0 . 2 2}$ & 0.15 & -0.04 \\
\hline MID A & 0.16 & $\mathbf{0 . 2 1}$ & & $\mathbf{0 . 2 3}$ & -0.02 & $\mathbf{- 0 . 3 6}$ \\
\hline MID B & $\mathbf{- 0 . 2 2}$ & $\mathbf{0 . 2 3}$ & $\mathbf{0 . 3 3}$ & & $\mathbf{0 . 4 7}$ & $-\mathbf{0 . 3 3}$ \\
\hline HIGH A & 0.15 & -0.02 & $\mathbf{0 . 4 7}$ & 0.13 & & 0.10 \\
\hline HIGH B & -0.04 & $\mathbf{- 0 . 3 6}$ & $\mathbf{- 0 . 3 3}$ & 0.10 & $\mathbf{0 . 4 0}$ & \\
\hline
\end{tabular}

Significant at $\mathrm{p}<0.05$ correlation coefficients are bold. 
Table 4 Correlations of sub-set standard TRW chronologies with climatic factors of cold season, May and June.

\begin{tabular}{|c|c|c|c|c|c|c|}
\hline Climatic factor & LOW A & LOW B & MID A & MID B & HIGH A & HIGH B \\
\hline \multicolumn{7}{|c|}{$1951-2015$} \\
\hline T Nov*-Apr & 0.324 & 0.178 & 0.509 & 0.155 & 0.406 & -0.328 \\
\hline T May & -0.200 & -0.170 & -0.088 & 0.060 & 0.004 & 0.076 \\
\hline T Jun & 0.039 & -0.008 & -0.104 & -0.396 & 0.173 & 0.006 \\
\hline P Oct*-Dec* & 0.336 & 0.164 & 0.323 & -0.068 & 0.374 & -0.036 \\
\hline P May & 0.299 & 0.079 & 0.204 & -0.142 & 0.051 & -0.159 \\
\hline P Jun & -0.069 & -0.178 & 0.081 & 0.038 & 0.164 & -0.017 \\
\hline \multicolumn{7}{|c|}{$1951-1980$} \\
\hline T Nov*-Apr & 0.575 & 0.447 & -0.185 & -0.080 & 0.143 & -0.227 \\
\hline T May & -0.068 & -0.286 & -0.017 & -0.438 & -0.050 & 0.316 \\
\hline T Jun & 0.216 & 0.228 & -0.216 & -0.137 & 0.201 & -0.070 \\
\hline P Oct*-Dec* & 0.298 & 0.168 & -0.097 & 0.195 & 0.216 & -0.142 \\
\hline P May & 0.001 & 0.275 & -0.046 & $\mathbf{0 . 3 7 7}$ & 0.156 & -0.336 \\
\hline P Jun & 0.033 & -0.075 & -0.256 & -0.320 & -0.181 & -0.072 \\
\hline \multicolumn{7}{|c|}{$1981-2010$} \\
\hline T Nov*-Apr & -0.001 & -0.144 & -0.107 & -0.191 & -0.198 & -0.359 \\
\hline T May & -0.250 & -0.194 & -0.132 & -0.283 & -0.179 & -0.149 \\
\hline T Jun & -0.100 & -0.093 & -0.479 & -0.182 & 0.292 & 0.003 \\
\hline P Oct ${ }^{*}-$ Dec $^{*}$ & 0.250 & -0.036 & -0.154 & 0.292 & 0.409 & 0.250 \\
\hline P May & 0.362 & -0.027 & -0.131 & 0.225 & 0.033 & -0.023 \\
\hline P Jun & -0.282 & -0.336 & 0.279 & 0.104 & 0.303 & 0.107 \\
\hline
\end{tabular}

Significant correlation coefficients are bold (at $\mathrm{p}<0.05$ ) or bold italic (at $\mathrm{p}<0.10$ ). Months of the previous year are marked with an asterisk $\left(^{*}\right)$. 

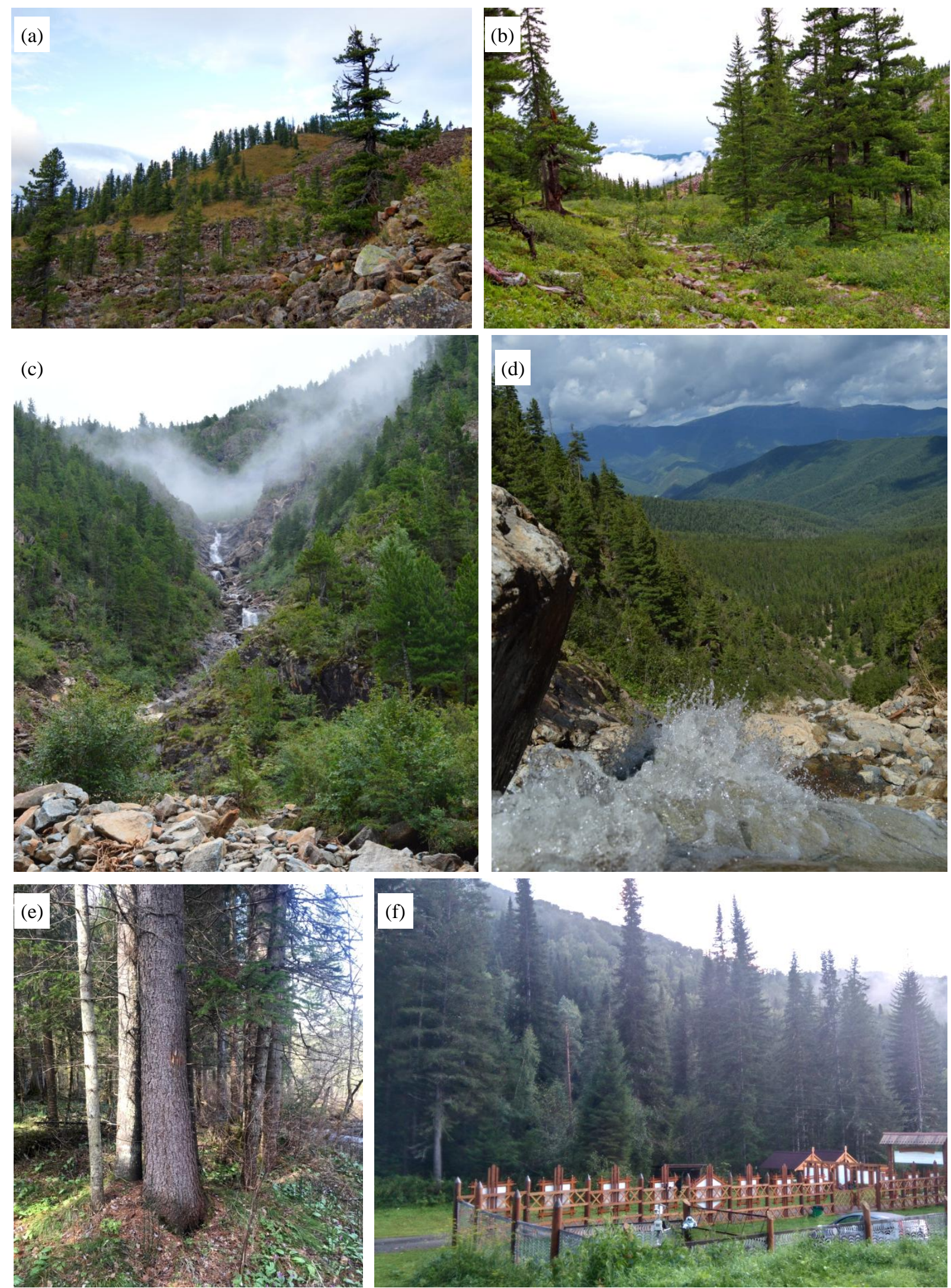

Appendix 1 Photo of sampling sites: HIGH - Pelekhov pass (a, b); MID - waterfall on the Talovka stream (c, d); LOW - Talovka camping (e, f). 
Appendix 2 Relationships of Cheryomushki (Cher) monthly climatic series (1951-2015) with corresponding series from Minusinsk (Min) and Olenya Rechka (OlR) stations estimated with linear regression.

\begin{tabular}{|c|c|c|c|c|c|c|}
\hline \multirow[b]{2}{*}{ Month } & \multicolumn{3}{|c|}{ Minusinsk } & \multicolumn{3}{|c|}{ Olenya Rechka } \\
\hline & equation & $\mathrm{R}^{2}$ & $\mathrm{R}$ & equation & $\mathrm{R}^{2}$ & $\mathrm{R}$ \\
\hline \multicolumn{7}{|c|}{ Temperature } \\
\hline Jan & $\mathrm{T}_{\text {Min }}=0.98 \mathrm{~T}_{\text {Cher }}-6.13$ & 0.780 & 0.883 & $\mathrm{~T}_{\text {OlR }}=0.54 \mathrm{~T}_{\text {Cher }}-11.24$ & 0.676 & 0.822 \\
\hline Feb & $\mathrm{T}_{\text {Min }}=0.98 \mathrm{~T}_{\text {Cher }}-5.98$ & 0.828 & 0.910 & $\mathrm{~T}_{\text {OlR }}=0.59 \mathrm{~T}_{\text {Cher }}-9.53$ & 0.762 & 0.873 \\
\hline Mar & $\mathrm{T}_{\text {Min }}=1.09 \mathrm{~T}_{\text {Cher }}-2.57$ & 0.880 & 0.938 & $\mathrm{~T}_{\mathrm{OlR}}=0.68 \mathrm{~T}_{\mathrm{Cher}}-7.06$ & 0.740 & 0.860 \\
\hline Apr & $\mathrm{T}_{\text {Min }}=1.03 \mathrm{~T}_{\text {Cher }}-0.56$ & 0.959 & 0.979 & $\mathrm{~T}_{\mathrm{OlR}}=1.11 \mathrm{~T}_{\text {Cher }}-7.56$ & 0.932 & 0.965 \\
\hline May & $\mathrm{T}_{\text {Min }}=1.03 \mathrm{~T}_{\text {Cher }}+0.03$ & 0.929 & 0.964 & $\mathrm{~T}_{\mathrm{OlR}}=1.09 \mathrm{~T}_{\mathrm{Cher}}-8.18$ & 0.890 & 0.943 \\
\hline Jun & $\mathrm{T}_{\text {Min }}=1.09 \mathrm{~T}_{\text {Cher }}-0.33$ & 0.845 & 0.919 & $\mathrm{~T}_{\text {OlR }}=1.07 \mathrm{~T}_{\text {Cher }}-7.40$ & 0.817 & 0.904 \\
\hline Jul & $\mathrm{T}_{\text {Min }}=1.03 \mathrm{~T}_{\text {Cher }}+0.75$ & 0.908 & 0.953 & TolR $=0.95 \mathrm{~T}_{\text {Cher }}-5.23$ & 0.827 & 0.910 \\
\hline Aug & $\mathrm{T}_{\text {Min }}=0.98 \mathrm{~T}_{\text {Cher }}+0.80$ & 0.895 & 0.946 & $\mathrm{~T}_{\mathrm{OlR}}=1.10 \mathrm{~T}_{\text {Cher }}-7.48$ & 0.874 & 0.935 \\
\hline Sep & $\mathrm{T}_{\text {Min }}=0.85 \mathrm{~T}_{\text {Cher }}+0.98$ & 0.854 & 0.924 & $\mathrm{~T}_{\mathrm{OlR}}=1.08 \mathrm{~T}_{\mathrm{Cher}}-6.55$ & 0.641 & 0.801 \\
\hline Oct & $\mathrm{T}_{\text {Min }}=0.80 \mathrm{~T}_{\text {Cher }}-1.02$ & 0.831 & 0.912 & $\mathrm{~T}_{\mathrm{OlR}}=0.85 \mathrm{~T}_{\text {Cher }}-6.12$ & 0.785 & 0.886 \\
\hline Nov & $\mathrm{T}_{\text {Min }}=0.96 \mathrm{~T}_{\text {Cher }}-3.74$ & 0.864 & 0.930 & $\mathrm{~T}_{\mathrm{OIR}}=0.63 \mathrm{~T}_{\mathrm{Cher}}-8.63$ & 0.770 & 0.877 \\
\hline Dec & $\mathrm{T}_{\text {Min }}=0.93 \mathrm{~T}_{\text {Cher }}-6.10$ & 0.805 & 0.897 & $\mathrm{~T}_{\text {OlR }}=0.52 \mathrm{~T}_{\text {Cher }}-11.3$ & 0.738 & 0.853 \\
\hline \multicolumn{7}{|c|}{ Precipitation } \\
\hline Jan & $P_{\text {Min }}=0.41 \mathrm{P}_{\text {Cher }}+3.8$ & 0.254 & 0.503 & $\mathrm{P}_{\mathrm{OlR}}=1.45 \mathrm{P}_{\mathrm{Cher}}+31.1$ & 0.147 & 0.384 \\
\hline Feb & $\mathrm{P}_{\text {Min }}=0.44 \mathrm{P}_{\text {Cher }}+2.4$ & 0.435 & 0.659 & $P_{\text {OlR }}=2.01 P_{\text {Cher }}+21.3$ & 0.416 & 0.645 \\
\hline Mar & $\mathrm{P}_{\text {Min }}=0.37 \mathrm{P}_{\text {Cher }}+2.6$ & 0.315 & 0.561 & $\mathrm{P}_{\mathrm{OlR}}=2.20 \mathrm{P}_{\mathrm{Cher}}+35.7$ & 0.348 & 0.590 \\
\hline Apr & $\mathrm{P}_{\text {Min }}=0.26 \mathrm{P}_{\text {Cher }}+7.2$ & 0.334 & 0.578 & $\mathrm{P}_{\mathrm{OIR}}=1.67 \mathrm{P}_{\mathrm{Cher}}+46.9$ & 0.613 & 0.783 \\
\hline May & $\mathrm{P}_{\text {Min }}=0.30 \mathrm{P}_{\text {Cher }}+15.0$ & 0.350 & 0.592 & $P_{\text {olR }}=1.11 P_{\text {Cher }}+50.4$ & 0.544 & 0.737 \\
\hline Jun & $P_{\text {Min }}=0.53 P_{\text {Cher }}+13.1$ & 0.428 & 0.654 & $\mathrm{P}_{\mathrm{OlR}}=0.61 \mathrm{P}_{\text {Cher }}+80.1$ & 0.190 & 0.436 \\
\hline Jul & $P_{\text {Min }}=0.34 P_{\text {Cher }}+32.4$ & 0.209 & 0.457 & $P_{\text {OlR }}=0.41 P_{\text {Cher }}+136$ & 0.068 & 0.261 \\
\hline Aug & $P_{\text {Min }}=0.43 P_{\text {Cher }}+22.4$ & 0.181 & 0.425 & $\mathrm{P}_{\mathrm{OIR}}=0.88 \mathrm{P}_{\text {Cher }}+90.0$ & 0.359 & 0.599 \\
\hline Sep & $\mathrm{P}_{\text {Min }}=0.54 \mathrm{P}_{\text {Cher }}+12.8$ & 0.430 & 0.656 & $\mathrm{P}_{\mathrm{OlR}}=1.06 \mathrm{P}_{\text {Cher }}+57.8$ & 0.450 & 0.671 \\
\hline Oct & $P_{\text {Min }}=0.33 P_{\text {Cher }}+12.2$ & 0.463 & 0.681 & $\mathrm{P}_{\mathrm{OIR}}=1.43 \mathrm{P}_{\text {Cher }}+50.8$ & 0.700 & 0.836 \\
\hline Nov & $\mathrm{P}_{\text {Min }}=0.33 \mathrm{P}_{\text {Cher }}+6.7$ & 0.339 & 0.582 & $\mathrm{P}_{\mathrm{OlR}}=1.90 \mathrm{P}_{\mathrm{Cher}}++50.0$ & 0.461 & 0.679 \\
\hline Dec & $\mathrm{P}_{\text {Min }}=0.45 \mathrm{P}_{\text {Cher }}+3.9$ & 0.356 & 0.597 & $\mathrm{P}_{\mathrm{OlR}}=2.88 \mathrm{P}_{\text {Cher }}+\mathbf{2 8 . 2}$ & 0.295 & 0.543 \\
\hline
\end{tabular}

All correlation coefficients (R) are significant at $\mathrm{p}<0.05$
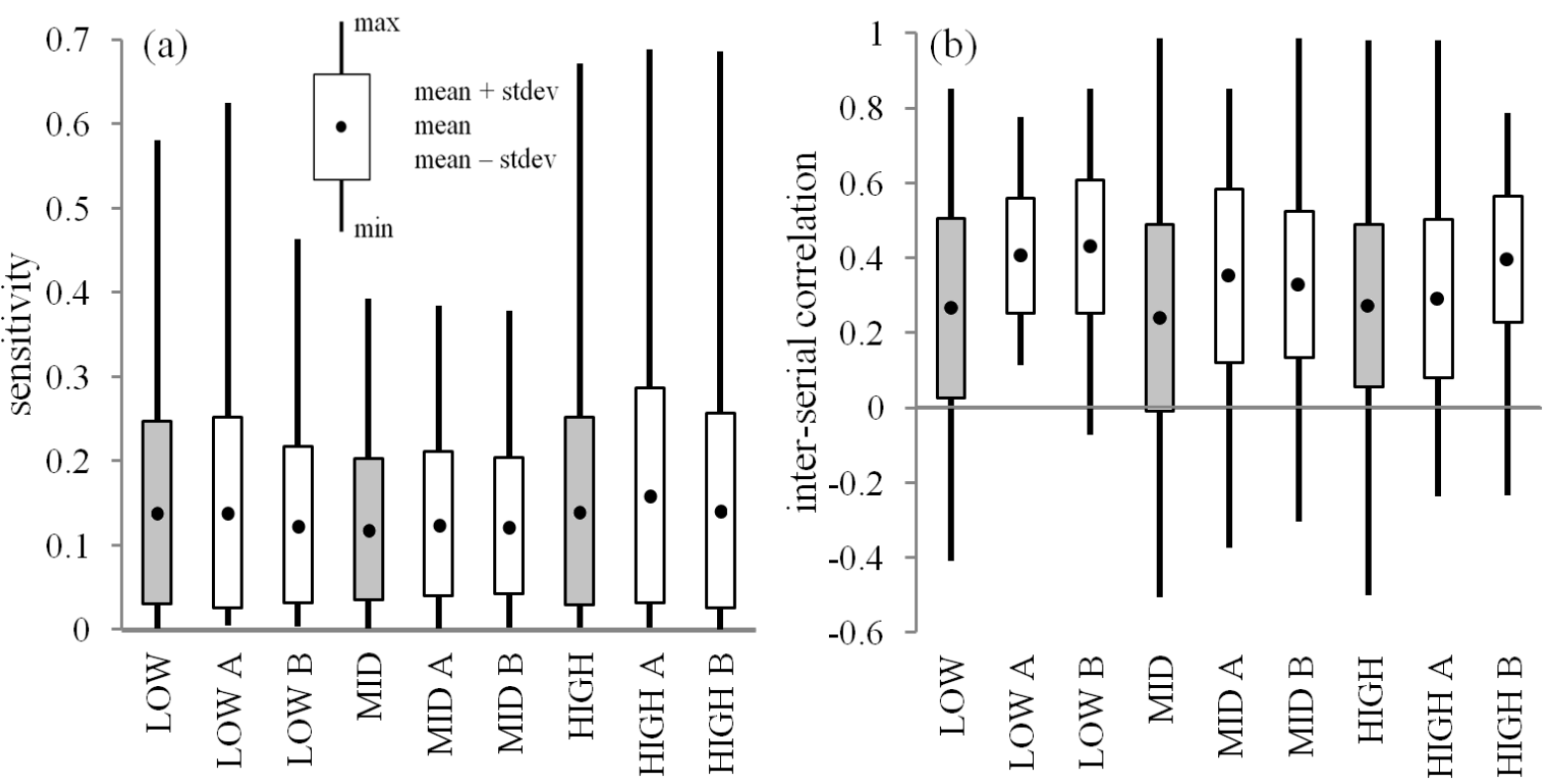

Appendix 3 Distributions of Picea obovata TRW statistical characteristics: sensitivity coefficients for local/sub-set chronologies during all their time span (a), and inter-serial correlation coefficients for local sets and sub-sets of individual TRW series (b). 


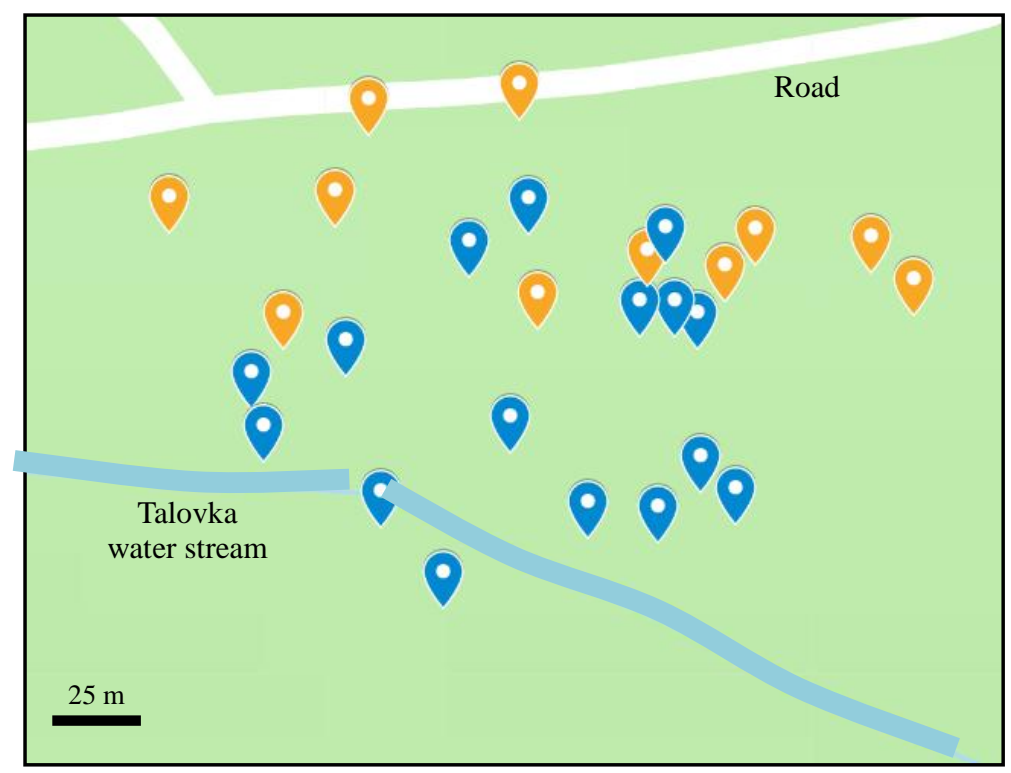

Appendix 4 Location scheme of trees classified into A (orange marks) and B (blue marks) sub-sets on example of LOW sampling site 